\title{
下顎前突症手術後の舌圧の経時的な变化について
}

\author{
成田幸憲
}

\section{Changes in tongue pressure before and after surgical correction for mandibular prognathism}

\author{
Takanori NARITA
}

\begin{abstract}
Although skeletal mandibular prognathism can be corrected by various surgical procedures, the tongue is always pushed backward by the retruded mandibular after surgery, resulting in an increase of reactive tongue pressure to the mandibular dental arch. This change of tongue pressure seems one of causes of relapse after surgery. This is a study on the changes in tongue pressure to the mandibular dental arch when pronouncing various sounds during one year before and after sagittal splitting osteotomy in 21 cases ( 5 males and 16 females). After a cantilever type pressure transducer utilizing a strain gauge was attached to the lingual aspect of the anterior teeth and the molar teeth on both sides, the pressure of the tongue during the pronounciation of ten Japanese sounds was measured before and 3 , 6 , and 12 months after the operation.
\end{abstract}

The results were follows.

1. The pressure to the mandibular dental arch greatly varied according to the sounds pronounced.

2. The pressure on the molar teeth was higher than that on the anterior teeth.

3. For one year, the pressure on the anterior teeth after operation was continuously higher than before.

4. For one year, the pressure on the right molar teeth after operation was continuously lower than before.

5. The pressure on the left molar teeth was higher 3 months after the operation than before but decreased gradually resulting in a lower level than the preoperatie pressure 12 months after surgery.

6. Considered as a whole, the increase in postoperative tongue pressure is not so high after sagittal splitting osteotomy, so that partial glossectomy at the same time does not seem to be clinically absolutely necessary.

Key words: tongue pressure, pronunciation, mandibular prognathism

愛知学院大学画学部第 2 口腔外科学教室 (主任：河合 幹教授)

The Second Department of Oral and Maxillo-facial Surgery, School of Dentistry, Aichi-Gakuin University (Chief: Prof. Tsuyoshi Kawai)

受付日：昭和 62 年 5 月 23 日
緒

$\overline{\overline{\bar{\sigma}}}$

骨格型下罘前突症の治療法としては外科的矯正法が適 応となるが，その術式は下靧技部を分割あるいは切断し て下㴿骨の骨体部とともに歯列弓全体を移動させるも の, あるいは下澒骨骨体部を切断して前方幽列のみを移 動させる方法, 同しく前方歯列の移動を行らにも歯槽部 
表 1 症例一筧表

\begin{tabular}{|c|c|c|c|c|c|c|c|}
\hline \multirow{2}{*}{$\begin{array}{l}\text { 症例 } \\
\text { No. }\end{array}$} & \multirow{2}{*}{ 年 龄 } & \multirow{2}{*}{ 性別 } & \multirow{2}{*}{$\begin{array}{l}\text { 年践) } \\
\text { (成) }\end{array}$} & \multicolumn{2}{|c|}{ 後退量 (mm) } & \multicolumn{2}{|c|}{ 知正治筷 } \\
\hline & & & & 右 㑡 & 左 渭 & 政前 & 继後 \\
\hline 1 & & 女 & 20 & 6.5 & 8.5 & 有 & 有 \\
\hline 2 & & 男 & 20 & 8.0 & 8.0 & 有 & 有 \\
\hline 3 & & 男 & 20 & 12.0 & 4.0 & 無 & 無 \\
\hline 4 & & 女 & 25 & 9.0 & 9.0 & 有 & 有 \\
\hline 5 & & 女 & 20 & 8.0 & 4.0 & 無 & 無 \\
\hline 6 & & 女 & 19 & 13.0 & 13.5 & 有 & 有 \\
\hline 7 & & 女 & 18 & 2.0 & 6.5 & 有 & 有 \\
\hline 8 & & 女 & 18 & 15.0 & 10.0 & 有 & 有 \\
\hline 9 & & 女 & 25 & 8.0 & 8.0 & 有 & 有 \\
\hline 10 & & 女 & 22 & 6.5 & 4.0 & 無 & 有 \\
\hline 11 & & 男 & 27 & 8.5 & -7.5 & 有 & 有 \\
\hline 12 & & 女 & 22 & 8.0 & 7.0 & 無 & 無 \\
\hline 13 & & 女 & 18 & 5.0 & 5.0 & 無 & 無 \\
\hline 14 & & 女 & 20 & 11.0 & 10.0 & 有 & 有 \\
\hline 15 & & 女 & 21 & 8.0 & 8.5 & 有 & 有 \\
\hline 16 & & 女 & 19 & 11.0 & 9.5 & 有 & 有 \\
\hline 17 & & 男 & 20 & 6.5 & 7.0 & 有 & 有 \\
\hline 18 & & 女 & 18 & 10.0 & 8.5 & 有 & 有 \\
\hline 19 & & 男 & 17 & 10.0 & 10.0 & 有 & 有 \\
\hline 20 & & 女 & 18 & 5.0 . & 3.0 & 有 & 有 \\
\hline 21 & & 女 & 20 & 15.0 & 13.0 & 有 & 有 \\
\hline
\end{tabular}

のみの骨切りにとどめる方法など症例に応じて使い分け られている。乙かしこれらいずれの術式を選択してる口 腔周縁組織の環境変化は急激かつ多大であり，特に口腔 内容皘の減少は固有口腔の大部分を占める舌にとっては その影響を直接的に受けることとなる。舌は発音，阻 罯，曖下などの機能を果たす時はもちろんのこと非機能

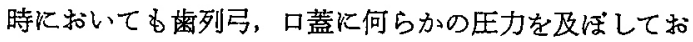
り，人工的にしかむ急激に下䫇歯列弓を後退，移動させ れば歯列弓に加わる舌代にる変化が生ずるはずである。

大喜多 ${ }^{11}$ ， 览玉 ${ }^{2}$ は実験的に舌房を縮小させ，舌圧の変 化を観察したが，舌房縮小により明らかに舌圧が増加し た事実を報告している，また下效後退術による舌圧の変 化については，日比野ら゙)，冨田ら")，が下顎安静時，

與下時, 示指吸引時, 舌最大突出時の下䫇前歯部に加わ る舌圧の变化を調查し報告している，本研究に扰いては 舌の重要な機能の一つである発音に着目し，外科的矯正 治療が適応となった骨格型下顠前突症例について下額後

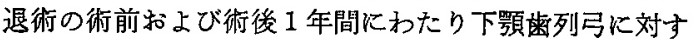
る発語時舌压の経時的な変化を前歯部と左右大曰歯部に ついて観察し考察を加えた。

\section{研 究方 法}

\section{1. 対象症例}

本研究の対象とした症例は骨格型下罰前突症と㟝断さ れ，外科的矯正治療が適応となった男珄 5 名, 女性 16 名 の計21例症で，年龄は17〜27歳（平均年龄20.3歳）であ

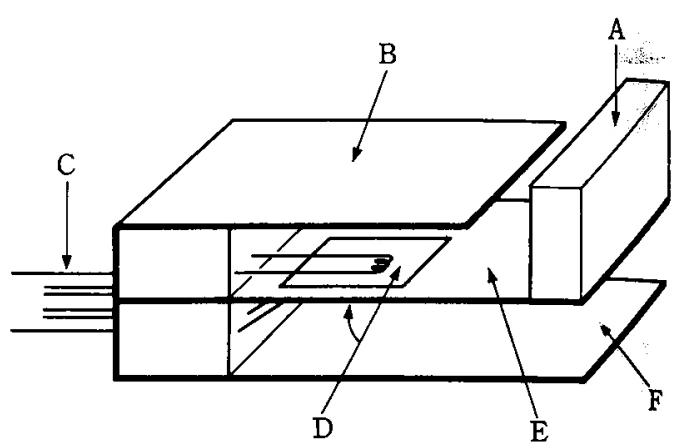

$$
\begin{aligned}
& \text { A：受压面Ｂ：プロテクター C ：リードワ } \\
& \text { イヤー D：Uずみゲージ（2 枚） } \mathrm{E} \text { ：カン }
\end{aligned}
$$$$
\text { チレバー（受圧板） F：外側板 }
$$

図 1 受王装置の構造

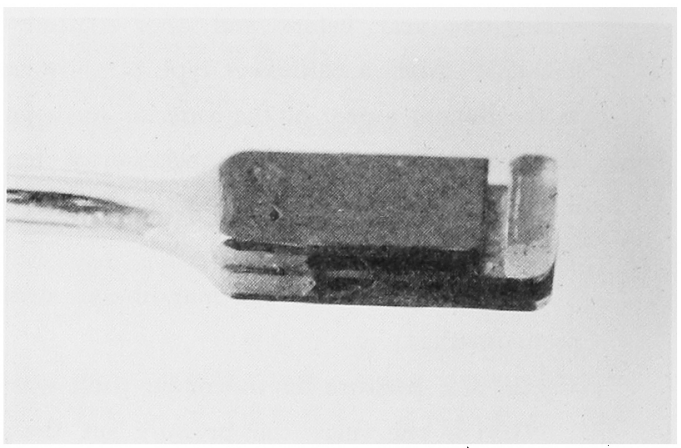

写真 1 受告装置の外観

った，手衍はすべて下顎枝矢状分割法 (Obwegeser-Dal Pont 法）により行われ，下顕の後方移動量は右側が $2.0 \mathrm{~mm} \sim 15.0 \mathrm{~mm}$ (平均 $8.9 \mathrm{~mm}$ ), 左側が $3.0 \mathrm{~mm} \sim$ $13.5 \mathrm{~mm}$ (平均 $7.8 \mathrm{~mm}$ ) であった. 矯正治療に関して は, 術後矯正治療のみ女行ったもの1例, 術前術後にわ たり矯正治療を行ったもの16例, 全く稪正治療を行わな かったるのが 4 例であった（表 1).

\section{2. 測定蟢置}

舌圧を感知する受正装置の構造および珄能については 以前に口腔筋圧の测定方法として報告したように方，リ ン青銅板と䇴ひずみケージを用いて独自に製作した，外 形は長径 $8 \mathrm{~mm}$, 幅径 $4 \mathrm{~mm}$, 厚径 $1.6 \mathrm{~mm}$ の直方体で プロテクターと外側板がカンチレバー（受生板）をはさ み込んだ 3 層棈造となっている。温度変化の激しい 口腔内の測定に適するよらに2アクティブゲージ法を採 用し温度補償機能を備えている（図 1, 写真 1 ).

\section{3. 測定方法}

本研究に招いては被験者の下顠齿列に受纴装置を設值 し，発音時に生ずる舌王を記録し術前および術後の数時 


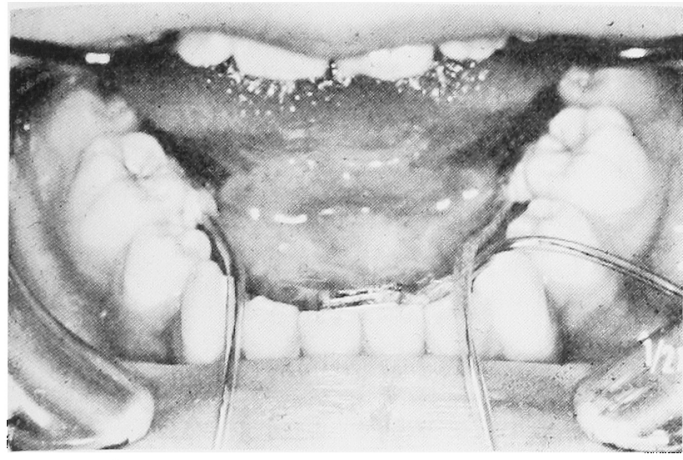

写真 2 受圧装置の下顎噒列舌側への設置 $(\overline{6}|,| \overline{6}, \overline{1 \mid 1}$ 部)

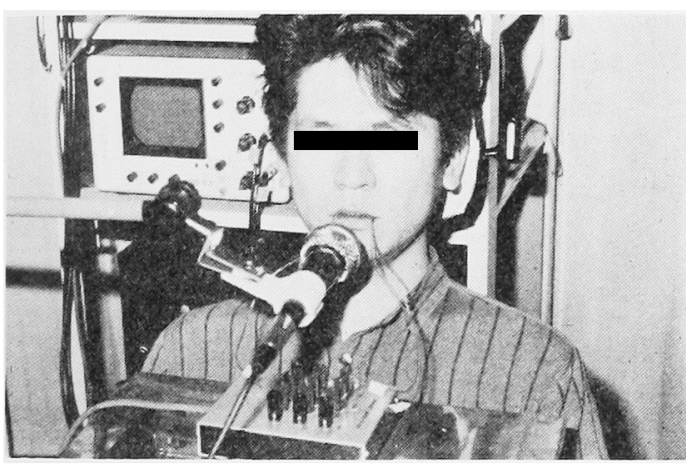

写真 3 舌圧測定中の頭位扣よび器機の設置状態

点にわたり経時的な变化を観察した。

1）受王装置の口腔内設置

設置部位は下顎の左右大臼雪部 2 力所 $(\overline{6}|,| \overline{6})$ と

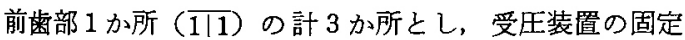
を確実にするためすべて荬牙の舌側歯面に值接固着した (写真 2)，その方法はまず即時重合レジンを盛り上げ雷 牙に压接し、レジンが便化するのを待ってロ腔外でトリ ミングを行い雷面への接着は瞬間接着郕を用いた。

2) 舌圧および音声の同時記録

下頡歯列弓の舌側 3 か所に設置した受圧装置により感 知された舌压は電压に変換されブリッジ回路, 增幅器を 経てデータレコーダに入力される。方，発語時の音声 はマイクロフォン, 增幅器を介してデータレコーダに入 カされ発語により生じた 3 か所の舌圧と音声とをカセッ トテープに同時集録した．また測定中はデータレューダ に入力される舌圧波形を同時にオンロスコープでモ二タ 一できるよらにした，分析の際にはカセットテープに集 録されたデータをペソ書きオシログラフに再生し計測を 行った（図2).

3) 测定時期

舌圧測定は(1)術前, (2) 術後約 3 力月, (3) 術後約 6 か

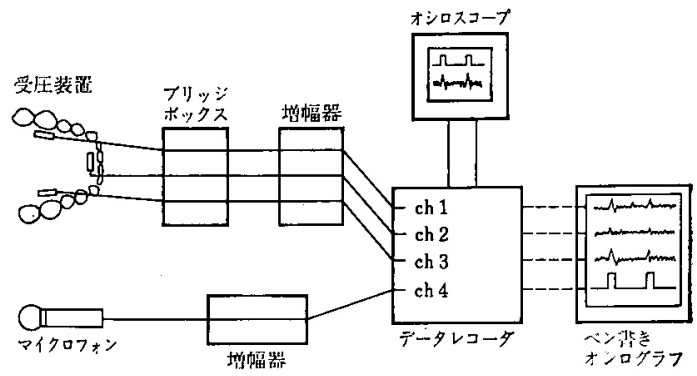

図 2 ブロックダイアグラム

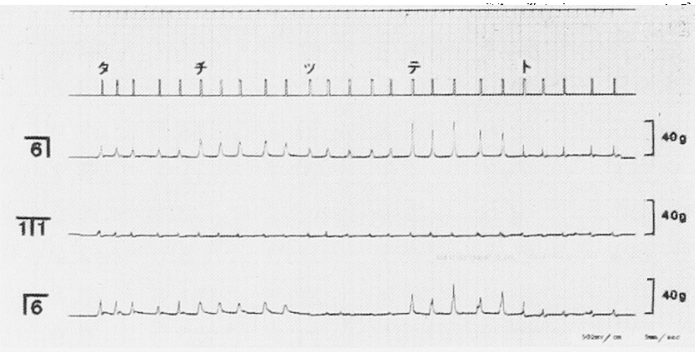

図 3 発語時の舌压波形

月，(4) 術後約 12 か力の 4 回とし，手術から 1 年間の経 時的な変化を観察した，な扰術前の測定は可能なかぎり 手術に近い時期に行らよらにした。

4) 測定条件

被験者に発音させる被験音として構音点が歯列にある [夕]行音, [ナ]行音, [ラ]行音, [ダ]行音, [シ 巾] 行音, [チャ] 行音, $[=+]$ 行音, [ジャ] 行音な どの雨茎音と[サ]行音，〔ザ]行音などの歯音，市わ せて40語音を選び各語につき 5 回ずつ験者の発語のあと に続いて復唱させた。 マイクロフォンの位置は口唇から $3 \mathrm{~cm}$ の距離に固定し，発語時の音声の大きさが設定し た範囲内にあるか否かをモニターできるようにマイクロ フォンからの回路に工夫をした，湘定時の姿勢は背もた れを最前部まで起こした状態のデンタルチェアーに深く 座らせ，なるべく楽に発音のしやすい状態とした，その 際の頭位はフランクフルト平面とカンペル平面との中間 が床と平行になるように固定した（写真了）.

5) 分析方法

分析の際にはまずデータレコーダのカセットテープに 集録されたデータをペン書きオシログラフに再生し記録 紙上に舌仕波形を描かせるが，ペン書きオシログラフは

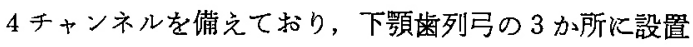
された受圧装置が感知した舌压と，発語時に感知された 音声を信号化し同時に記録紙上に描き出すことができる （図了）. 図了に执いて最上段に描かれている長方形の波 形が音声を信号化したものであり，この波形は発語時の 音声の大ささが設定された節囲内にあるときのみに表示 
表 2 [夕]発語時における舌王の变化

\begin{tabular}{|c|c|c|c|c|c|c|c|c|c|c|c|c|}
\hline 部位 & \multicolumn{4}{|c|}{$\overline{6} \mid$} & \multicolumn{4}{|c|}{$\overline{1 / 1}$} & \multicolumn{4}{|c|}{$\sqrt{6}$} \\
\hline $\begin{array}{l}\text { 経 過 } \\
\text { 症例 No. }\end{array}$ & 政前 & $\begin{array}{l}\text { 衒 後 } \\
3 \text { 员 }\end{array}$ & $\begin{array}{l}\text { 政 後 } \\
6 \text { 员 }\end{array}$ & $\begin{array}{l}\text { 愁 後 } \\
12 \text { 月 }\end{array}$ & 術前 & $\begin{array}{l}\text { 很 後 } \\
3 \text { 员 }\end{array}$ & $\begin{array}{l}\text { 術 後 } \\
6 \text { 力月 }\end{array}$ & $\begin{array}{l}\text { 徏 後 } \\
12 \text { 员 }\end{array}$ & 犹前 & $\begin{array}{l}\text { 徏 後 } \\
3 \text { 员 }\end{array}$ & $\begin{array}{l}\text { 政 後 } \\
6 \text { 员 }\end{array}$ & $\begin{array}{l}\text { 趡 後 } \\
12 \text { 月 }\end{array}$ \\
\hline 1 & 3.4 & 3. 3 & 4.5 & 8.1 & 4.8 & 5.0 & 1. 2 & 9.6 & 7.6 & 4.6 & 6.2 & 6.9 \\
\hline 2 & 5.1 & 9.3 & 6.1 & 6.4 & 0.8 & 5.6 & 3. 1 & 3.8 & 7.3 & 6.5 & 5.9 & 8.3 \\
\hline 3 & 5.7 & 11.4 & 7.6 & 7. 1 & 4.8 & 2.6 & 2.2 & 5.4 & 9.2 & 15.4 & 10.8 & 15.5 \\
\hline 4 & 6.4 & 12.3 & 12. 3 & 17.5 & 5. 7 & 2.9 & 5.0 & 4.1 & 12.5 & 8.8 & 8.5 & 7.9 \\
\hline 5 & 17.3 & 11.2 & 11.6 & 17.5 & 3. 2 & 5.0 & 1.6 & 2.3 & 9.5 & 9.5 & 11.0 & 11.0 \\
\hline 6 & 9.1 & 11.7 & 7.4 & 7.1 & 2.7 & 4.3 & 2.4 & 1.9 & 9.8 & 10.1 & 10.3 & 5.2 \\
\hline 7 & 9.8 & 2.7 & 7.8 & 10.4 & 1.2 & 4.0 & 4.4 & 0.6 & 6.6 & 8.1 & 9.6 & 6.2 \\
\hline 8 & 5.4 & 23.0 & 15.5 & 17.7 & 2.2 & 2.4 & 1.9 & 2.3 & 4.8 & 14.0 & 16.2 & 6.3 \\
\hline 9 & 10.0 & 10.8 & 11.4 & 13.9 & 3. 6 & 1.0 & 2.7 & 3.5 & 16.4 & 7.1 & 8.9 & 4.2 \\
\hline 10 & 9.0 & 17.4 & 11.3 & 18.9 & 9.4 & 7.8 & 5.6 & 3. 9 & 4.8 & 12.7 & 10.7 & 5.6 \\
\hline 11 & 6.2 & 4.3 & 10.7 & 11.1 & 5.2 & 7.8 & 4.4 & 5.7 & 6.6 & 14.1 & 8.7 & 12.4 \\
\hline 12 & 2.6 & 2.1 & 3.2 & 2.2 & 1.5 & 1.8 & 2.6 & 7.1 & 6.6 & 4.6 & 4.8 & 4.0 \\
\hline 13 & 11.1 & 14.5 & 12.3 & 8.0 & 2. 2 & 1.9 & 3. 4 & 4.5 & 9.7 & 12.6 & 19.0 & 15.2 \\
\hline 14 & 19.9 & 20.0 & 22.9 & 14.8 & 0.8 & 3. 0 & 4. 6 & 3.3 & 14.8 & 10.9 & 13.4 & 6.2 \\
\hline 15 & 17.7 & 12.7 & 21.8 & 10. 2 & 5.9 & 2.8 & 1.7 & 2.6 & 19.3 & 14.3 & 7.0 & 12.3 \\
\hline 16 & 9.8 & 20.0 & 12.7 & 11.8 & 1.0 & 2.0 & 2.2 & 3.0 & 13.0 & 13.8 & 11.3 & 7.6 \\
\hline 17 & 4.2 & 7.4 & 7.9 & 5. 0 & 1.8 & 2.6 & 5.0 & 8.1 & 4.8 & 3.3 & 4.2 & 5.6 \\
\hline 18 & 25.9 & 10.7 & 8.9 & 23.0 & 2.0 & 2.3 & 1.2 & 3.3 & 17.4 & 22.3 & 14.8 & 15.6 \\
\hline 19 & 22.7 & 9.2 & 29. 2 & 21.4 & 6.3 & 7.9 & 8.8 & 11.0 & 17.4 & 25.1 & 27.4 & 22.4 \\
\hline 20 & 20.2 & 12.4 & 6.0 & 9.8 & 3.9 & 7.2 & 1.9 & 2.3 & 7.4 & 17.4 & 3.1 & 4.6 \\
\hline 21 & 19. 9 & 6.9 & 11.8 & 4.6 & 2.0 & 2.4 & 4.4 & 4.2 & 6.7 & 5.9 & 9.7 & 3.0 \\
\hline 平均值 & 11.5 & 11.1 & 11.6 & 11.7 & 3. 4 & 3.9 & 3. 3 & 4.4 & 10.1 & 11.5 & 10.5 & 8.9 \\
\hline S.D. & 7.1 & 5.7 & 6.4 & 5.8 & 2.2 & 2.2 & 1.9 & 2.6 & 4.6 & 5.7 & 5.5 & 5.0 \\
\hline
\end{tabular}

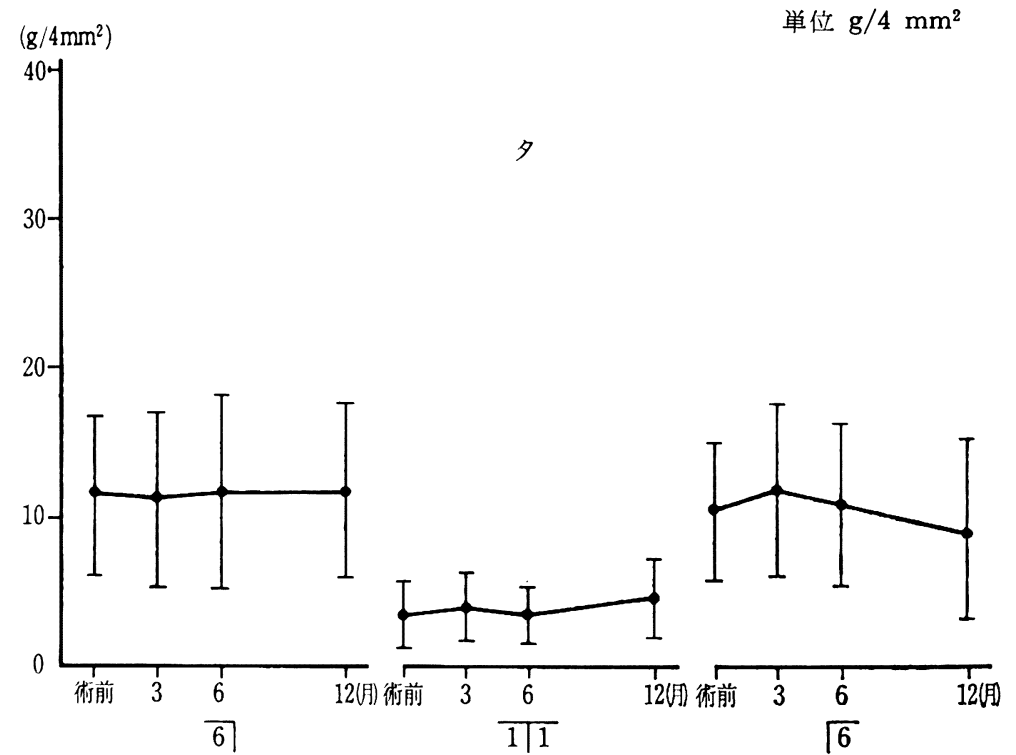

图 4〔夕〕発語時に打ける舌压の変化 
表 $3[千]$ 発語時における舌王の変化

\begin{tabular}{|c|c|c|c|c|c|c|c|c|c|c|c|c|}
\hline 部位 & \multicolumn{4}{|c|}{$\overline{6}$} & \multicolumn{4}{|c|}{$\overline{111}$} & \multicolumn{4}{|c|}{$\sqrt{6}$} \\
\hline 症例No. & 術前 & $\begin{array}{l}\text { 術 後 } \\
3 \text { 加 }\end{array}$ & $\begin{array}{l}\text { 術 後 } \\
6 \text { 力月 }\end{array}$ & $\begin{array}{l}\text { 術 後 } \\
12 \text { 月 }\end{array}$ & 術前 & $\begin{array}{l}\text { 術 後 } \\
3 \text { か月 }\end{array}$ & $\begin{array}{l}\text { 政 後 } \\
6 \text { 力月 }\end{array}$ & $\begin{array}{l}\text { 術 後 } \\
12 \text { 员 }\end{array}$ & 術前 & $\begin{array}{l}\text { 術 後 } \\
3 \text { 力月 }\end{array}$ & $\begin{array}{l}\text { 術 後 } \\
6 \text { 力月 }\end{array}$ & $\begin{array}{l}\text { 術 後 } \\
12 \text { 员 }\end{array}$ \\
\hline 1 & 20.4 & 6.7 & 11.0 & 10.7 & 3.3 & 4.1 & 3.8 & 6.7 & 25.5 & 8.3 & 11.6 & 10.4 \\
\hline 2 & 4.5 & 5.3 & 6.9 & 8.8 & 0.7 & 3.9 & 2.2 & 2.7 & 3. 0 & 2.4 & $8 \cdot 5$ & 4.7 \\
\hline 3 & 8.1 & 8.0 & 3.4 & 8.2 & 1. 3 & 1.7 & 1.9 & 2.5 & 6. 2 & 13.7 & 6.7 & 7.2 \\
\hline 4 & 5.1 & 6.0 & 8.2 & 8.2 & 1.8 & 2.1 & 3.7 & 1.7 & 7.4 & 5.3 & 7.4 & 8.1 \\
\hline 5 & 21.0 & 16.9 & 11.0 & 10.6 & 5.6 & 3.3 & 1.9 & 2.2 & 12.1 & 6.0 & 5.6 & 5.4 \\
\hline 6 & 10.2 & 10.6 & 11.7 & 17.9 & 1.4 & 4.9 & 1.5 & 0.8 & 15.5 & 14.3 & 15.6 & 13.2 \\
\hline 7 & 5.5 & 1.8 & 4.8 & 5.4 & 1.8 & 2.5 & 2.3 & 0.4 & 2.9 & 5.2 & 4.1 & 3.4 \\
\hline 8 & 13.8 & 15.0 & 11. 2 & 9.7 & 1. 4 & 6.2 & 2.2 & 1. 3 & 5.5 & 10.2 & 9.9 & 3. 2 \\
\hline 9 & 15.7 & 11.2 & 12.0 & 11.6 & 3. 3 & 9.5 & 1.1 & 2.4 & 13.0 & 9.3 & 13.0 & 7.7 \\
\hline 10 & 4.9 & 8.8 & 6.9 & 7.0 & 2.0 & 5.4 & 2.5 & 1.8 & 3. 4 & 7.5 & 6.3 & 2.3 \\
\hline 11 & 4.4 & 2.9 & 3. 3 & 1.7 & 0.9 & 2.6 & 2.2 & 1. 1 & 3. 1 & 3.9 & 3.7 & 2.0 \\
\hline 12 & 2.1 & 3. 2 & 6.0 & 3. 0 & 0.9 & 2.0 & 2.6 & 7. 0 & 5.4 & 2.8 & 10.4 & 4.5 \\
\hline 13 & 5.6 & 7.0 & 7. 9 & 5.3 & 1. 3 & 1.9 & 1.8 & 2.6 & 4.0 & 4. 9 & 6.7 & 6.0 \\
\hline 14 & 8.9 & 9.5 & 10. 1 & 5.7 & 0.4 & 3. 1 & 1.8 & 2.9 & 9.3 & 9.7 & 11.4 & 6.8 \\
\hline 15 & 14.9 & 15.6 & 22.8 & 12.4 & 1. 2 & 2.1 & 1.8 & 2.1 & 13.6 & 25.2 & 3. 3 & 9.4 \\
\hline 16 & 5.4 & 13.5 & 6.6 & 5.2 & 0.7 & 2.2 & 1. 8 & 1.9 & 7.0 & 7.2 & 4.9 & 3. 6 \\
\hline 17 & 4.5 & 10.3 & 11.1 & 11.5 & 1. 2 & 2.1 & 3. 6 & 5. 0 & 3.0 & 4. 2 & 4.3 & 7.9 \\
\hline 18 & 8.4 & 9.8 & 9.5 & 12.3 & 0.3 & 3. 6 & 1. 2 & 1. 2 & 4.8 & 25.9 & 11.0 & 14.9 \\
\hline 19 & 27.0 & 3. 2 & 14.0 & 10.6 & 13.0 & 9.0 & 8.8 & 10.6 & 18.6 & 15.6 & 19.3 & 12.5 \\
\hline 20 & 38.8 & 39.2 & 16. 3 & 21.8 & 5.9 & 2.1 & 0.8 & 0.9 & 22.2 & 49. 6 & 18. 9 & 23.3 \\
\hline 21 & 13. 2 & 4.9 & 16. 3 & 4. 8 & 0 & 1. 3 & 1. 7 & 1. 3 & 4.6 & 2.6 & 8. 6 & 2.8 \\
\hline 平均値 & 11.5 & 10.0 & 10.0 & 9.2 & 2.3 & 3. 6 & 2.4 & 2.8 & 9.1 & 11.1 & 9.1 & 7.6 \\
\hline S.D. & 9.1 & 8.0 & 4. 7 & 4.7 & 2.9 & 2.3 & 1.7 & 2.5 & 6.7 & 11.0 & 4.7 & 5.1 \\
\hline
\end{tabular}

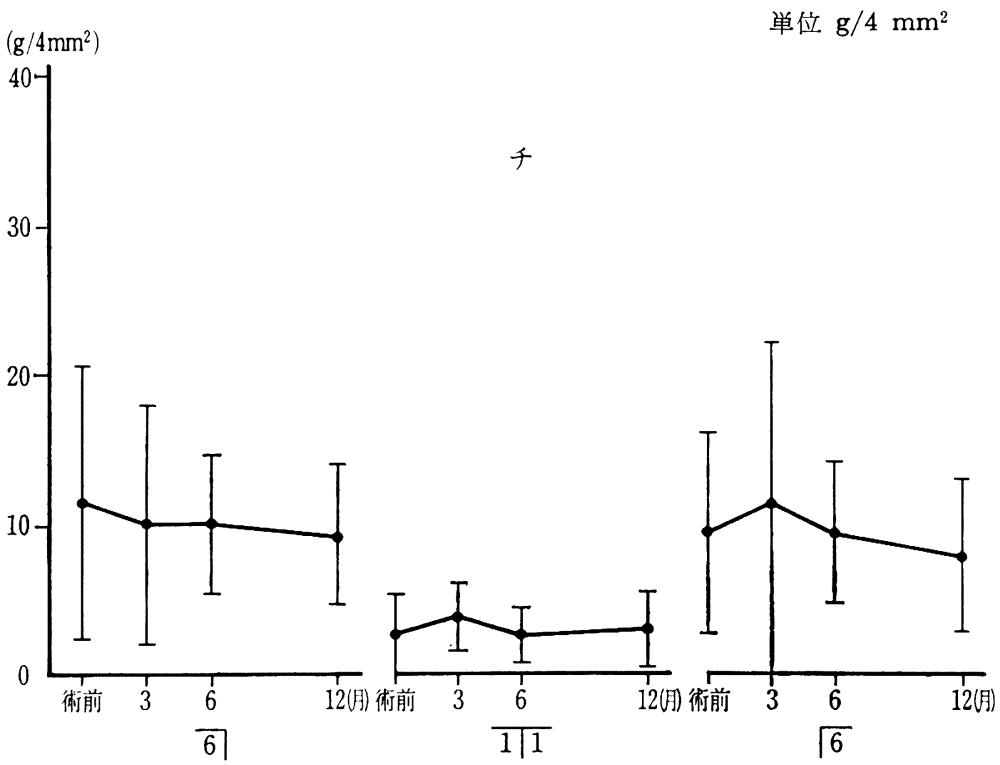

図 5 [千]発語時における舌压の変化 
表 4 [ッ]発語時における舌圧の変化

\begin{tabular}{|c|c|c|c|c|c|c|c|c|c|c|c|c|}
\hline \multirow{2}{*}{ 症例No. 経 } & \multicolumn{4}{|c|}{$\overline{6} \mid$} & \multicolumn{4}{|c|}{$\overline{1 / 1}$} & \multicolumn{4}{|c|}{$\sqrt{6}$} \\
\hline & 術前 & $\begin{array}{l}\text { 垛 後 } \\
3 \text { か }\end{array}$ & $\begin{array}{l}\text { 政 後 } \\
6 \text { 力 }\end{array}$ & $\begin{array}{l}\text { 術 後 } \\
12 \text { 月 }\end{array}$ & 術前 & 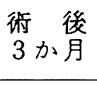 & $\begin{array}{l}\text { 政 後 } \\
6 \text { 力 }\end{array}$ & $\begin{array}{l}\text { 愁 後 } \\
12 \text { 员 }\end{array}$ & 術前 & $\begin{array}{l}\text { 政 } \\
3 \text { 後 }\end{array}$ & 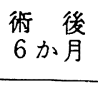 & $\begin{array}{l}\text { 堔 後 } \\
12 \text { 加月 }\end{array}$ \\
\hline 1 & 4.7 & 3.8 & 5.5 & 4.3 & 6.0 & 3.4 & 5.2 & 8.8 & 6.3 & 3.9 & 5.3 & 5.5 \\
\hline 2 & 3. 0 & 3.6 & 4. 2 & 5.8 & 2.0 & 5.7 & 3.7 & 4.0 & 8.7 & 2.5 & 6.2 & 9.2 \\
\hline 3 & 7.7 & 10.4 & 4.1 & 3.6 & 2.8 & 4.8 & 3. 2 & 2.9 & 8.8 & 10.4 & 7.6 & 9.1 \\
\hline 4 & 2.5 & 4.0 & 5.0 & 6.7 & 3. 2 & 2.4 & 4.0 & 2.3 & 2.9 & 2.4 & 2.4 & 6.3 \\
\hline 5 & 12.6 & 5.7 & 5.0 & 5.1 & 5.0 & 3. 6 & 0.8 & 2.1 & 7.4 & 5.4 & 4.5 & 3.7 \\
\hline 6 & 1.0 & 2.1 & 1.6 & 7.0 & 1.1 & 3. 0 & 1.2 & 1.5 & 1.5 & 1.9 & 2.2 & 4.3 \\
\hline 7 & 3. 0 & 1.8 & 1.2 & 4.0 & 2.6 & 2.8 & 2.3 & 0.8 & 2.4 & 7.1 & 1.6 & 2.5 \\
\hline 8 & 5.9 & 11.6 & 5.8 & 3. 0 & 1.6 & 3.8 & 4.6 & 1.4 & 8.8 & 3.9 & 3.9 & 1.1 \\
\hline 9 & 8.8 & 8.0 & 8.4 & 5.4 & 4.1 & 7.5 & 3. 0 & 3.6 & 2.0 & 2.3 & 1.9 & 5.0 \\
\hline 10 & 3. 4 & 5.1 & 4. 8 & 5.3 & 4. 2 & 5.6 & 2.3 & 3.4 & 4.9 & 4.5 & 6.1 & 1.6 \\
\hline 11 & 10.4 & 4.5 & 4.9 & 4.5 & 3.6 & 2.6 & 2.1 & 2.2 & 5.0 & 5.8 & 3.2 & 3.7 \\
\hline 12 & 3. 4 & 2.2 & 6.1 & 2.9 & 1.0 & 1.8 & 4.1 & 9.0 & 6.5 & 2.2 & 4.0 & 3.3 \\
\hline 13 & 5.4 & 5.0 & 2.8 & 2.2 & 2.4 & 2.5 & 3.3 & 4.2 & 3. 3 & 2.0 & 3.0 & 2.7 \\
\hline 14 & 5.8 & 3.4 & 5.6 & 3.1 & 0.4 & 3. 3 & 1.7 & 2.5 & 7.0 & 4.1 & 8.8 & 6.1 \\
\hline 15 & 8.7 & 8.7 & 13. 2 & 6.0 & 2.3 & 2.2 & 1.1 & 2.1 & 4.8 & 9.1 & 2.9 & 4.9 \\
\hline 16 & 4.6 & 10.6 & 3.7 & 3.3 & 1.0 & 3.8 & 1.7 & 1.9 & 5.8 & 5.2 & 2.4 & 2.7 \\
\hline 17 & 8.4 & 6.0 & 4. 2 & 3.9 & 2.0 & 2.5 & 5.1 & 7.4 & 2.3 & 2.2 & 2.5 & 2.7 \\
\hline 18 & 10.4 & 5.3 & 10.1 & 4.8 & 1.0 & 1.7 & 2.4 & 1.2 & 7.6 & 17.7 & 13.1 & 6.3 \\
\hline 19 & 15.4 & 4.1 & 11.3 & 9.4 & 7.5 & 5.0 & 6.1 & 5.4 & 15.4 & 14.0 & 19.5 & 15.8 \\
\hline 20 & 11.4 & 6.2 & 1.3 & 1.8 & 3.8 & 2.6 & 1.2 & 0.9 & 4.9 & 5.7 & 2.6 & 4.2 \\
\hline 21 & 2.9 & 2.4 & 4.1 & 1.8 & 1.0 & 1.5 & 2.4 & 1.8 & 2.0 & 2.2 & 2.4 & 1.0 \\
\hline 平均値 & 6.6 & 5.5 & 5. 4 & 4.5 & 2.8 & 3.4 & 2.9 & 3.3 & 5.6 & 5.5 & 5.1 & 4.8 \\
\hline S.D. & 3.9 & 2.9 & 3.1 & 1.9 & 1.8 & 1.5 & 1.5 & 2.4 & 3.3 & 4.2 & 4.3 & 3.4 \\
\hline
\end{tabular}
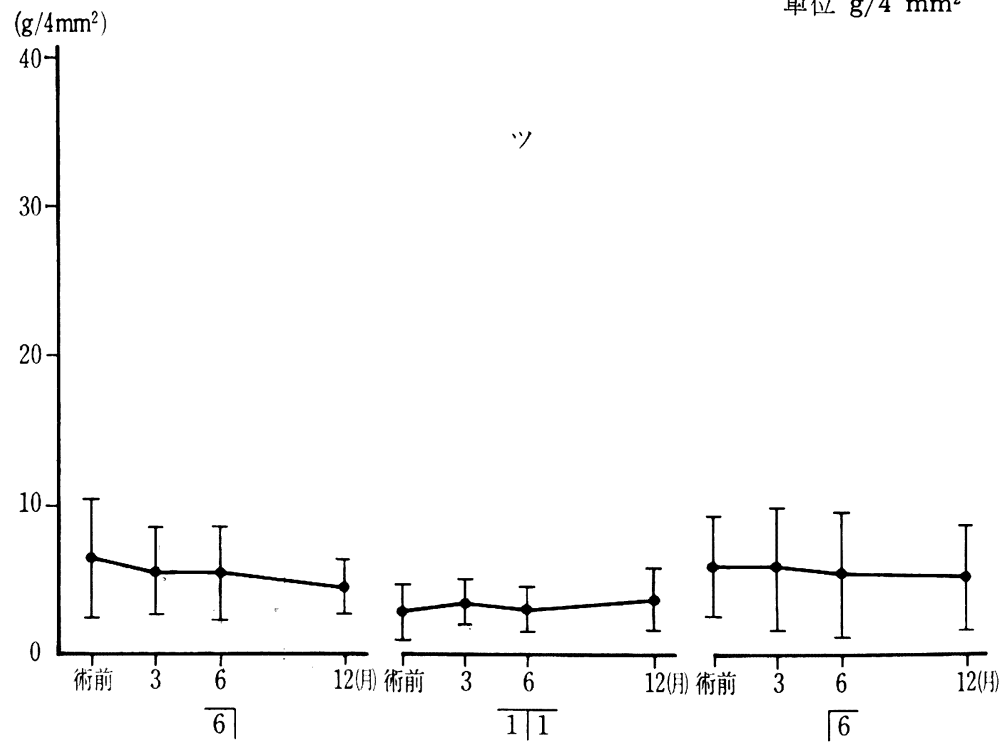

図 6 〔ッ〕発語時に扰ける舌王の変化 
表 5 〔テ]発語時における舌圧の変化

\begin{tabular}{|c|c|c|c|c|c|c|c|c|c|c|c|c|}
\hline 部位 & \multicolumn{4}{|c|}{$\overline{6}$} & \multicolumn{4}{|c|}{$\overline{1 \mid 1}$} & \multicolumn{4}{|c|}{$\sqrt{6}$} \\
\hline 症例 No. 释 & 術前 & $\begin{array}{l}\text { 征 後 } \\
3 \text { か }\end{array}$ & $\begin{array}{l}\text { 術 後 } \\
6 \text { 力 }\end{array}$ & $\begin{array}{l}\text { 術 後 } \\
12 \text { 月 }\end{array}$ & 術前 & $\begin{array}{l}\text { 術 後 } \\
3 \text { 力 }\end{array}$ & $\begin{array}{l}\text { 術 後 } \\
6 \text { 只 }\end{array}$ & $\begin{array}{l}\text { 術 後 } \\
12 \text { 月 }\end{array}$ & 術前 & $\begin{array}{l}\text { 術 後 } \\
3 \text { 力 }\end{array}$ & $\begin{array}{l}\text { 術 後 } \\
6 \text { 只 }\end{array}$ & $\begin{array}{l}\text { 術 後 } \\
12 \text { 月 }\end{array}$ \\
\hline 1 & 3.8 & 4.5 & 5.3 & 7.9 & 5.5 & 3.4 & 1. 1 & 7.3 & 9.7 & 7.4 & 8.0 & 9.1 \\
\hline 2 & 9.6 & 11.8 & 8.1 & 9.2 & 1.8 & 5.5 & 3.5 & 3.6 & 9.0 & 5.8 & 9.7 & 8.8 \\
\hline 3 & 15.2 & 8.9 & 11.0 & 12.5 & 1.8 & 2.4 & 1.6 & 2.1 & 27.5 & 14.6 & 11.3 & 18.3 \\
\hline 4 & 9.6 & 13.2 & 18.8 & 16.5 & 4.4 & 2.5 & 6.6 & 6.3 & 13.6 & 14.1 & 14.3 & 19.6 \\
\hline 5 & 12.1 & 14.0 & 11.5 & 11.8 & 0.8 & 3.9 & 1.3 & 1.1 & 9.6 & 14.3 & 7.6 & 10.7 \\
\hline 6 & 21.8 & 27.6 & 23.9 & 34.8 & 3. 6 & 4.2 & 2.2 & 2.9 & 13.9 & 30.5 & 28.4 & 21.6 \\
\hline 7 & 33.4 & 5.5 & 19.9 & 19.6 & 3. 6 & 3.8 & 2.8 & 0.6 & 15.7 & 12.4 & 21.7 & 19.0 \\
\hline 8 & 12.2 & 37.1 & 16.0 & 22.4 & 1.7 & 2.6 & 2.5 & 1.8 & 9.8 & 24.2 & 15.1 & 12.7 \\
\hline 9 & 31.7 & 29.5 & 32.0 & 36.5 & 3.6 & 4.5 & 4.0 & 5.7 & 21.4 & 24.9 & 25.3 & 20.3 \\
\hline 10 & 11.7 & 17.8 & 11.0 & 24.2 & 5.3 & 9.6 & 5.3 & 4.8 & 5.5 & 14.5 & 12.9 & 6.9 \\
\hline 11 & 10.1 & 3.1 & 10.8 & 5.8 & 3. 6 & 4.6 & 3. 2 & 4.5 & 7.1 & 11.9 & 14.0 & 5.6 \\
\hline 12 & 3. 6 & 1.8 & 3.3 & 2.2 & 1.5 & 1.5 & 2.2 & 5.5 & 11.7 & 2.5 & 7.4 & 6.8 \\
\hline 13 & 15.0 & 16.5 & 10.9 & 6.3 & 2.9 & 2.0 & 3. 4 & 4. 1 & 11.0 & 10.8 & 14.8 & 9.8 \\
\hline 14 & 28. 4 & 20.2 & 22.5 & 17.7 & 0.7 & 1.0 & 3. 2 & 2.2 & 28.3 & 27.0 & 18.6 & 12.6 \\
\hline 15 & 33.6 & 34.9 & 27.5 & 23. 2 & 4. 3 & 2.2 & 2. 2 & 2.8 & 30.4 & 36.3 & 4.2 & 23.7 \\
\hline 16 & 5.4 & 11.4 & 7.2 & 14.0 & 0.9 & 1.4 & 1.2 & 4.4 & 11.4 & 12.0 & 6.1 & 8.4 \\
\hline 17 & 9.1 & 9.5 & 12.4 & 3.6 & 2.6 & 2.9 & 4.6 & 4.6 & 11.2 & 6.4 & 5.8 & 4. 1 \\
\hline 18 & 32.1 & 9.3 & 13.3 & 13.3 & 1.0 & 2.3 & 1.9 & 1.2 & 34.7 & 23.6 & 26.6 & 22.0 \\
\hline 19 & 30.0 & 16.0 & 40.5 & 24.4 & 9.2 & 7.1 & 9.2 & 7.6 & 27.6 & 29.9 & 47.8 & 30.7 \\
\hline 20 & 50.8 & 58.1 & 19.4 & 27.4 & 4. 6 & 4.5 & 2.1 & 1.9 & 27.8 & 55.9 & 18.5 & 22.0 \\
\hline 21 & 30.2 & 11.4 & 14.4 & 14.1 & 1.1 & 2.0 & 3.5 & 7.8 & 15.1 & 19.7 & 17.9 & 9.3 \\
\hline 平均値 & 19.5 & 17.2 & 16. 2 & 16.5 & 3. 1 & 3.5 & 3.2 & 3.9 & 16.8 & 19.0 & 16.0 & 14.4 \\
\hline S.D. & 12.8 & 13.6 & 9.2 & 9.6 & 2.1 & 2.1 & 2.0 & 2.2 & 8.9 & 12.4 & 10.1 & 7.3 \\
\hline
\end{tabular}

$\left(\mathrm{g} / 4 \mathrm{~mm}^{2}\right)$

単位 $\mathrm{g} / 4 \mathrm{~mm}^{2}$ S.D. 標準偏差

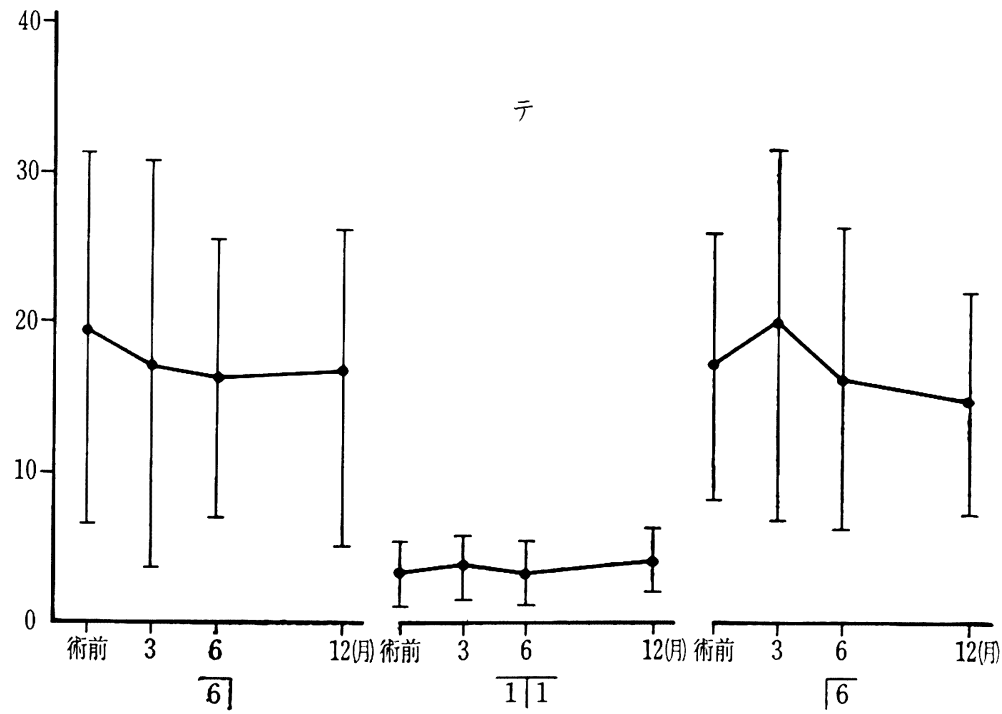

図 7 [テ〕発語時に打外る舌圧の変化 
表 6 [ト]発語時における舌圧の変化

\begin{tabular}{|c|c|c|c|c|c|c|c|c|c|c|c|c|}
\hline \multirow{2}{*}{ 経過 } & \multicolumn{4}{|c|}{$\overline{6} \mid$} & \multicolumn{4}{|c|}{$\overline{1 \mid 1}$} & \multicolumn{4}{|c|}{$1 \overline{6}$} \\
\hline & 術前 & $\begin{array}{l}\text { 堔 後 } \\
3 \text { か周 }\end{array}$ & $\begin{array}{l}\text { 政 後 } \\
6 \text { 员 } \\
\end{array}$ & $\begin{array}{l}\text { 街 後 } \\
12 \text { 月 }\end{array}$ & 術前 & $\begin{array}{l}\text { 㭪 後 } \\
3 \text { か周 }\end{array}$ & $\begin{array}{l}\text { 政 後 } \\
6 \text { 员 } \\
\end{array}$ & $\begin{array}{l}\text { 術 後 } \\
12 \text { 月 }\end{array}$ & 術前 & $\begin{array}{l}\text { 政 後 } \\
3 \text { か用 }\end{array}$ & $\begin{array}{l}\text { 街 後 } \\
6 \text { か } \\
\end{array}$ & $\begin{array}{l}\text { 趡 後 } \\
12 \text { 员 }\end{array}$ \\
\hline 1 & 5.0 & 4.1 & 5.9 & 7.1 & 4.7 & 5.8 & 1.0 & 11.4 & 8.9 & 5.0 & 7.8 & 9.8 \\
\hline 2 & 7.0 & 8.3 & 7.0 & 7.3 & 2.3 & 4.3 & 3.4 & 3. 3 & 11.1 & 6.5 & 6.3 & 7.4 \\
\hline 3 & 6.8 & 7.2 & 7. 1 & 9.2 & 3.4 & 2.0 & 3.3 & 3.8 & 8.5 & 8.2 & 8.6 & 10.8 \\
\hline 4 & 5.2 & 6.1 & 5.8 & 9.0 & 4.2 & 2.2 & 8.5 & 3. 3 & 8.2 & 5.2 & 5.0 & 10.4 \\
\hline 5 & 13.8 & 9.6 & 9.5 & 9.6 & 2.6 & 3.9 & 1.0 & 2.0 & 8.9 & 5.6 & 7.1 & 6.4 \\
\hline 6 & 4.4 & 5.1 & 5.3 & 7.1 & 1.8 & 3.4 & 2.4 & 1.8 & 7.3 & 6.2 & 4.4 & 4.6 \\
\hline 7 & 5.8 & 2.0 & 5.1 & 5.8 & 2.8 & 3.8 & 2.6 & 0 & 4.2 & 6.4 & 5.4 & 5.0 \\
\hline 8 & 7.8 & 18.0 & 10.2 & 19.8 & 2.0 & 7.9 & 2.6 & 1.2 & 6.4 & 14.2 & 13.0 & 3.7 \\
\hline 9 & 11.9 & 9.3 & 5.4 & 13. 4 & 3.0 & 2.4 & 3.4 & 5.0 & 6.2 & 4.8 & 6.2 & 4.5 \\
\hline 10 & 9.2 & 10.5 & 7.5 & 9.0 & 7.1 & 10.5 & 5.7 & 7.0 & 5.3 & 11.0 & 8.3 & 5.1 \\
\hline 11 & 11.3 & 6.2 & 7.1 & 10.4 & 4.7 & 9.1 & 2.4 & 4.7 & 5.9 & 14.4 & 8.1 & 9.7 \\
\hline 12 & 2.5 & 2.4 & 5.2 & 1.7 & 1.4 & 1.2 & 2.6 & 6.1 & 15.7 & 2.6 & 10.6 & 6.3 \\
\hline 13 & 15.8 & 13.8 & 8.6 & 6.1 & 3.1 & 1.8 & 3.8 & 3. 8 & 10.1 & 10.0 & 11.8 & 10.2 \\
\hline 14 & 22.2 & 9.2 & 23.1 & 16.4 & 1.3 & 3.0 & 4.4 & 1.8 & 9.7 & 8.3 & 6.9 & 3.1 \\
\hline 15 & 10.9 & 7.2 & 15.3 & 6.5 & 3.4 & 1.9 & 1.4 & 3.1 & 16.4 & 10.7 & 5.0 & 8.1 \\
\hline 16 & 7.6 & 15.1 & 14.6 & 6.2 & 0.8 & 1.7 & 1.3 & 2.6 & 8.7 & 10.5 & 7.5 & 6.8 \\
\hline 17 & 4. 3 & 6.7 & 8.0 & 7.8 & 1. 0 & 1.7 & 3.7 & 6.4 & 2.8 & 2.9 & 2.7 & 5.9 \\
\hline 18 & 13.8 & 7.8 & 7.3 & 11.9 & 1.3 & 1.5 & 2.9 & 2.0 & 13.3 & 17.0 & 13.6 & 10.5 \\
\hline 19 & 36.8 & 10.7 & 31.9 & 23.1 & 9.1 & 11.8 & 9.2 & 9.2 & 28.0 & 37.6 & 32.7 & 20.6 \\
\hline 20 & 13.3 & 11.7 & 4. 3 & 7.4 & 3. 6 & 4.2 & 1.8 & 1.8 & 5.6 & 10.5 & 2.2 & 3.9 \\
\hline 21 & 20.3 & 9.5 & 12.3 & 5.8 & 1.7 & 3.2 & 4.5 & 3.9 & 6.6 & 5.4 & 9.8 & 2.8 \\
\hline 平均値 & 11.2 & 8.6 & 9.8 & 9. 6 & 3.1 & 4.2 & 3.4 & 4.0 & 9.4 & 9.7 & 8.7 & 7.4 \\
\hline S.D. & 7.9 & 4. 0 & 6.7 & 5.0 & 2.1 & 3.1 & 2.2 & 2.8 & 5.5 & 7.5 & 6.3 & 4.0 \\
\hline
\end{tabular}

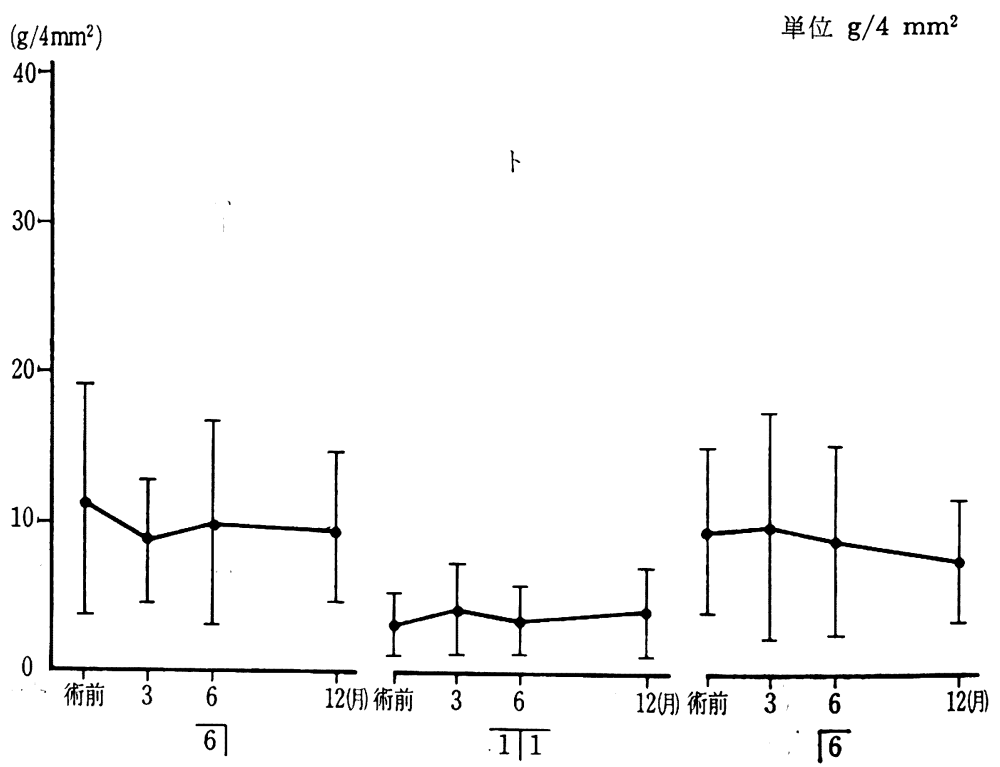

图 8 〔ト〕発語時における舌止の変化 
表 7 〔ナ〕発語時における舌圧の変化

\begin{tabular}{|c|c|c|c|c|c|c|c|c|c|c|c|c|}
\hline 部位 & \multicolumn{4}{|c|}{$\overline{6} \mid$} & \multicolumn{4}{|c|}{$\overline{1 / 1}$} & \multicolumn{4}{|c|}{$\sqrt{6}$} \\
\hline 症例 No. 経 & 術前 & $\begin{array}{l}\text { 愁 後 } \\
3 \text { か }\end{array}$ & $\begin{array}{l}\text { 政 後 } \\
6 \text { 力有 }\end{array}$ & $\begin{array}{l}\text { 術 後 } \\
12 \text { 月 }\end{array}$ & 術前 & $\begin{array}{l}\text { 術 後 } \\
3 \text { 力员 }\end{array}$ & $\begin{array}{l}\text { 很 後 } \\
6 \text { 员 }\end{array}$ & $\begin{array}{l}\text { 糹 } \\
12 \text { 後 }\end{array}$ & 術前 & 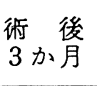 & $\begin{array}{l}\text { 喍 後 } \\
6 \text { 力用 }\end{array}$ & $\begin{array}{l}\text { 政 後 } \\
12 \text { 月 }\end{array}$ \\
\hline 1 & 5.8 & 3.3 & 5.4 & 7.9 & 4. 6 & 1.6 & 2.1 & 3. 3 & 10.9 & 5.2 & 8.0 & 8.9 \\
\hline 2 & 5.5 & 17.8 & 13.3 & 7.8 & 0.7 & 4.5 & 3.4 & 3.7 & 7. 0 & 8.0 & 12.8 & 9.4 \\
\hline 3 & 3.0 & 8.8 & 6.3 & 5.8 & 2.4 & 3. 2 & 2.4 & 3.6 & 6.2 & 6.3 & 8.3 & 8.8 \\
\hline 4 & 7.4 & 11.6 & 9.6 & 17.1 & 5.4 & 2.5 & 7.3 & 4.1 & 13. 2 & 11.9 & 9.9 & 15.2 \\
\hline 5 & 10.8 & 8.9 & 10.4 & 11.9 & 2.4 & 2.2 & 0.8 & 1.5 & 7.9 & 9.6 & 11.0 & 8.8 \\
\hline 6 & 6.6 & 11.7 & 13.3 & 13.4 & 1.8 & 4.5 & 3.1 & 1.5 & 8.3 & 14.0 & 16.4 & 6.9 \\
\hline 7 & 13.8 & 3. 2 & 10.2 & 11.8 & 2.2 & 3.2 & 1.9 & 0.4 & 6.8 & 8.6 & 8.0 & 8.2 \\
\hline 8 & 9.2 & 15.1 & 10.8 & 15.7 & 1. 3 & 1.9 & 2.0 & 1.5 & 6.2 & 12.6 & 10.7 & 6.6 \\
\hline 9 & 13.5 & 11.0 & 10.8 & 19.1 & 4.2 & 3.6 & 3.0 & 2.6 & 7.0 & 7.1 & 9.2 & 12.6 \\
\hline 10 & 9.6 & 18. 1 & 9.7 & 13.9 & 2.9 & 5.9 & 2.3 & 4. 0 & 3.7 & 9.7 & 5.4 & 4.9 \\
\hline 11 & 8.9 & 4.4 & 9.6 & 7.5 & 4.8 & 5.3 & 1.9 & 3.5 & 4.1 & 16. 2 & 7.7 & 9.4 \\
\hline 12 & 2.3 & 1.9 & 3.8 & 1.3 & 1. 2 & 1.8 & 2.1 & 5.9 & 7.8 & 2.9 & 5.5 & 5.2 \\
\hline 13 & 16.3 & 13. 3 & 10.8 & 7.6 & 2.3 & 1.7 & 0.6 & 3. 6 & 15.4 & 11.6 & 18.1 & 12.7 \\
\hline 14 & 26.1 & 15.0 & 17.1 & 12.0 & 0.8 & 3. 2 & 5.1 & 1.9 & 14.2 & 9.8 & 10.9 & 3.9 \\
\hline 15 & 17.1 & 11.2 & 12.4 & 9.8 & 4.3 & 2.1 & 1.6 & 2.3 & 16.6 & 15.1 & 2.7 & 9.5 \\
\hline 16 & 16.9 & 18.1 & 10.7 & 7.8 & 0.8 & 1.5 & 1.5 & 2.7 & 12.5 & 11.3 & 5.1 & 4.0 \\
\hline 17 & 5.4 & 7.6 & 10.8 & 6.3 & 1.3 & 2.8 & 4.8 & 6.9 & 5.0 & 3.6 & 3.4 & 4.4 \\
\hline 18 & 14.0 & 7.0 & 4.7 & 13.9 & 1.3 & 1.2 & 0.5 & 1.7 & 21.2 & 23.4 & 6.7 & 12.6 \\
\hline 19 & 21.7 & 8.7 & 20.1 & 16.1 & 6.0 & 6.8 & 7.9 & 8.2 & 17.6 & 19.3 & 23.6 & 16. 1 \\
\hline 20 & 16.3 & 20.8 & 11.9 & 9.9 & 4.1 & 5.3 & 2.8 & 2.8 & 6.6 & 31.9 & 13. 9 & 7.6 \\
\hline 21 & 19.5 & 15.4 & 13.5 & 4. 2 & 1.5 & 1.4 & 2.7 & 3.6 & 9.2 & 8.5 & 10.9 & 5.4 \\
\hline 平均値 & 11.9 & 11.1 & 10.7 & 10.5 & 2.7 & 3.2 & 2.9 & 3.3 & 9.9 & 11.7 & 9.9 & 8.6 \\
\hline S.D. & 6.4 & 5.4 & 3.8 & 4.6 & 1.7 & 1.6 & 2.0 & 1.9 & 4.9 & 6.8 & 5.0 & 3. 6 \\
\hline
\end{tabular}

$\left(\mathrm{g} / 4 \mathrm{~mm}^{2}\right)$

単位 $\mathrm{g} / 4 \mathrm{~mm}^{2} \quad$ S.D. 標淮偏差

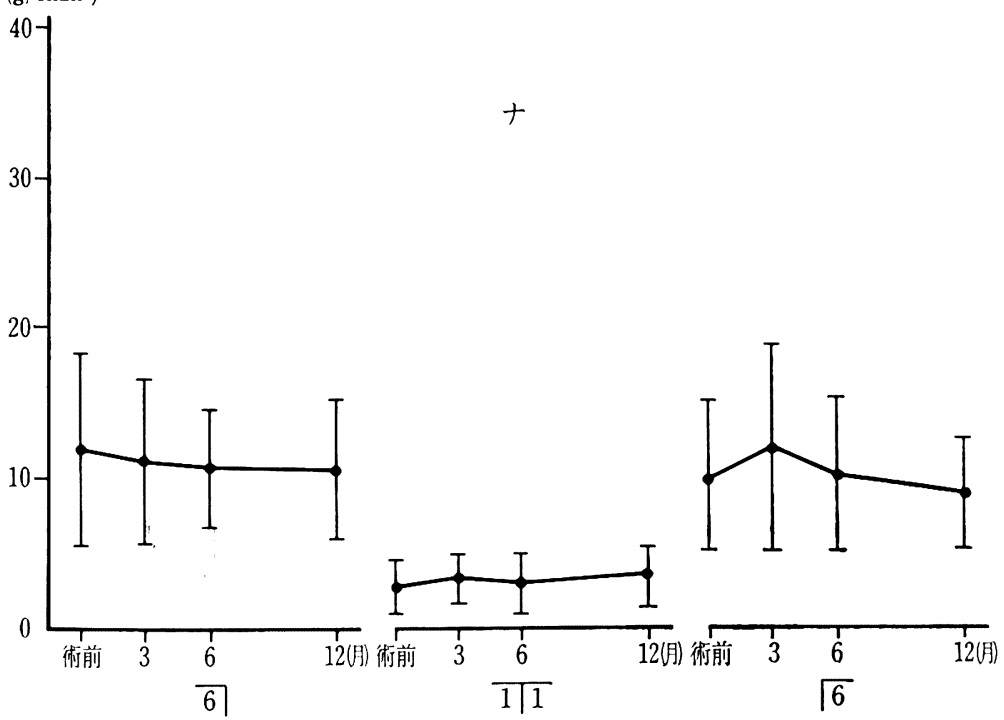

図 9〔ナ〕発語時に打ける舌圧の変化 
表 8 〔二発語時における舌圧の変化

\begin{tabular}{|c|c|c|c|c|c|c|c|c|c|c|c|c|}
\hline 部位 & \multicolumn{4}{|c|}{$\overline{6} \mid$} & \multicolumn{4}{|c|}{$\overline{1 / 1}$} & \multicolumn{4}{|c|}{$\sqrt{6}$} \\
\hline $\begin{array}{l}\text { 経過 } \\
\text { 例 No. }\end{array}$ & 術前 & $\begin{array}{l}\text { 政 後 } \\
3 \text { 员 }\end{array}$ & $\begin{array}{l}\text { 政 後 } \\
6 \text { 员 }\end{array}$ & $\begin{array}{l}\text { 術 後 } \\
12 \text { 员 }\end{array}$ & 術前 & $\begin{array}{l}\text { 術 後 } \\
3 \text { 员 }\end{array}$ & $\begin{array}{l}\text { 術 後 } \\
6 \text { 员 }\end{array}$ & $\begin{array}{l}\text { 術 後 } \\
12 \text { 年 }\end{array}$ & 術前 & $\begin{array}{l}\text { 政 後 } \\
3 \text { 员 }\end{array}$ & $\begin{array}{l}\text { 術 後 } \\
6 \text { 员 } \\
\end{array}$ & $\begin{array}{l}\text { 很 後 } \\
12 \text { 员 }\end{array}$ \\
\hline 1 & 17.3 & 10.2 & 10.6 & 16.3 & 2.6 & 3. 8 & 1.9 & 3.1 & 28.5 & 11.3 & 11.3 & 18.1 \\
\hline 2 & 12.6 & 15.1 & 11.4 & 7.2 & 1. 2 & 3.3 & 3.0 & 3.1 & 16.8 & 7.9 & 17.8 & 16.0 \\
\hline 3 & 12.9 & 13. 0 & 5.6 & 9.2 & 1.8 & 2.0 & 1.8 & 1.8 & 27.3 & 22.2 & 13. 8 & 13.1 \\
\hline 4 & 5.6 & 8.4 & 9.7 & 16.2 & 1.3 & 1.7 & 2.7 & 2.2 & 12.7 & 8.3 & 7.0 & 11.1 \\
\hline 5 & 23.8 & 16.7 & 14.8 & 16.2 & 1.9 & 1.7 & 1.3 & 1.2 & 12.6 & 9.3 & 18.7 & 15.3 \\
\hline 6 & 17.0 & 27.4 & 19.4 & 27.7 & 0.8 & 2.8 & 1.2 & 1.0 & 20.9 & 27.2 & 26.3 & 19.0 \\
\hline 7 & 12.2 & 3.4 & 9.1 & 8.9 & 1. 6 & 1. 0 & 2.1 & 0.2 & 6.8 & 8.2 & 8.4 & 5.1 \\
\hline 8 & 12.3 & 11.6 & 12.3 & 11.6 & 0.8 & 1.1 & 2.7 & 1.1 & 18.1 & 7.5 & 11.6 & 4.8 \\
\hline 9 & 25.6 & 10.0 & 18. 2 & 33. 9 & 2.6 & 4. 2 & 1.5 & 2.8 & 14.7 & 7.4 & 15.8 & 14.3 \\
\hline 10 & 9.7 & 17.9 & 16.1 & 18.2 & 2.1 & 4.4 & 2.4 & 2.8 & 4.9 & 10.0 & 7.6 & 4.6 \\
\hline 11 & 3.6 & 2.1 & 4. 1 & 2.8 & 1.6 & 1.9 & 1. 0 & 2.1 & 2.6 & 4. 0 & 2.9 & 2.9 \\
\hline 12 & 4.6 & 6.6 & 5.4 & 3.5 & 0 & 1.8 & 1.6 & 3.8 & 9.0 & 4.9 & 10.1 & 11.5 \\
\hline 13 & 5.2 & 6.6 & 8.6 & 6.2 & 0.8 & 0.9 & 0 & 0.6 & 4.5 & 4.2 & 10.7 & 7.1 \\
\hline 14 & 34.2 & 8.3 & 10.5 & 7.3 & 0.2 & 2.4 & 1.8 & 2.3 & 12.3 & 11.2 & 10.6 & 8.0 \\
\hline 15 & 35.2 & 23. 2 & 27.6 & 21.3 & 0.7 & 1.4 & 1.9 & 1.8 & 27.6 & 34.4 & 2.4 & 15.8 \\
\hline 16 & 17.8 & 23.3 & 11.2 & 7.6 & 0.8 & 1.0 & 1.6 & 1.8 & 14.8 & 8.9 & 8.8 & 3.7 \\
\hline 17 & 8.0 & 14.3 & 10.1 & 15.0 & 1.3 & 2.1 & 2.5 & 3.5 & 7.4 & 9.0 & 4.5 & 10.4 \\
\hline 18 & 12.2 & 6.3 & 6.1 & 10.1 & 0.9 & 1.3 & 0.8 & 2.0 & 8.5 & 22.6 & 13.3 & 12.9 \\
\hline 19 & 25.7 & 10.2 & 25.5 & 18.8 & 11.1 & 9.8 & 11.1 & 7.0 & 20.1 & 22.0 & 34.1 & 16.9 \\
\hline 20 & 40.4 & 32.3 & 19.4 & 25.3 & 1.3 & 1.9 & 1.4 & 1.6 & 24.5 & 39.1 & 21.6 & 22.6 \\
\hline 21 & 16.1 & 7.7 & 16.8 & 7.2 & 0 & 1.1 & 1.3 & 1.4 & 9.3 & 5.3 & 14.0 & 6.3 \\
\hline 平均値 & 16.8 & 13. 1 & 13.0 & 13.8 & 1.7 & 2.5 & 2.2 & 2.3 & 14.5 & 13.6 & 13.0 & 11.4 \\
\hline S.D. & 10.5 & 8.0 & 6.4 & 8.3 & 2.3 & 2.0 & 2.2 & 1.4 & 8.0 & 10.2 & 7.7 & 5.7 \\
\hline
\end{tabular}

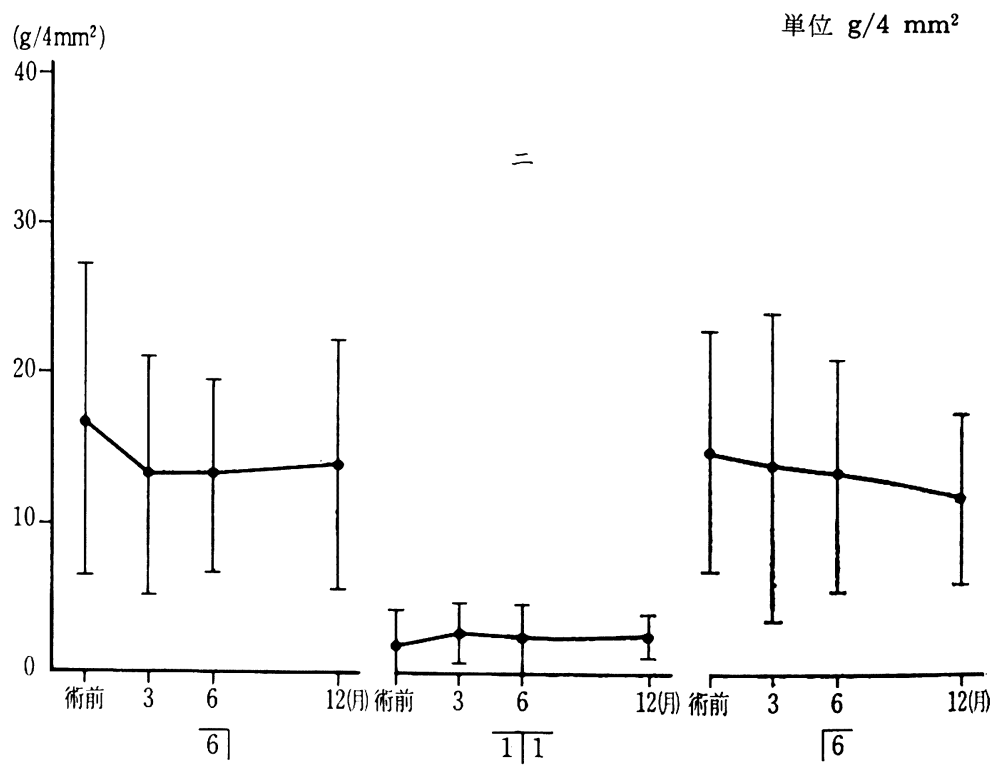

図 10 〔二]発語時に打ける舌圧の変化 
表 9 [邓]発語時に打忛る舌圧の変化

\begin{tabular}{|c|c|c|c|c|c|c|c|c|c|c|c|c|}
\hline 部位 & & & 5 & & & & & & & & $\overline{6}$ & \\
\hline 症例 No. & 術前 & $\begin{array}{l}\text { 術 後 } \\
3 \text { か月 }\end{array}$ & $\begin{array}{c}\text { 術 後 } \\
6 \text { 力月 }\end{array}$ & $\begin{array}{l}\text { 術 後 } \\
12 \text { 月 }\end{array}$ & 術前 & $\begin{array}{c}\text { 術 後 } \\
3 \text { 力月 }\end{array}$ & $\begin{array}{l}\text { 政後 } \\
6 \text { 加月 }\end{array}$ & $\begin{array}{l}\text { 術 後 } \\
12 \text { 力 }\end{array}$ & 術前 & $\begin{array}{l}\text { 術 後 } \\
3 \text { 加月 }\end{array}$ & $\begin{array}{l}\text { 術 後 } \\
6 \text { 加 }\end{array}$ & $\begin{array}{l}\text { 衍 後 } \\
12 \text { 员 }\end{array}$ \\
\hline 1 & 3.8 & 5.4 & 8. 3 & 9.1 & 3. 1 & 3. 4 & 2.4 & 4.7 & 9.1 & 6.8 & 7.8 & 8.4 \\
\hline 2 & 5.4 & 9.9 & 6.0 & 7.2 & 1.3 & 5.1 & 3.3 & 2.2 & 8.4 & 5.5 & 6.0 & 7.0 \\
\hline 3 & 4. 3 & 4. 4 & 3.9 & 5.7 & 1.8 & 2.3 & 2.0 & 1.8 & 10.4 & 8.3 & 6.5 & 7.0 \\
\hline 4 & 2.3 & 3.9 & 4.8 & 3. 4 & 4.1 & 3. 2 & 4.9 & 3.5 & 4.8 & 3.0 & 3.2 & 5.4 \\
\hline 5 & 3.7 & 5.6 & 2.3 & 4. 2 & 1. 6 & 2.1 & 0.7 & 1.0 & 4. 1 & 4. 3 & 2.7 & 5.0 \\
\hline 6 & 2.7 & 4. 6 & 4.6 & 5.2 & 0.9 & 1.6 & 1. 4 & 1.0 & 4. 6 & 4. 0 & 3.6 & 2.0 \\
\hline 7 & 6.5 & 1. 4 & 4. 4 & 9.0 & 1.6 & 1.3 & 1. 4 & 0.7 & 1.9 & 3. 0 & 1.8 & 2.5 \\
\hline 8 & 4. 1 & 13.6 & 9.8 & 6.2 & 1.9 & 2. 4 & 2.2 & 1.1 & 7.3 & 10.4 & 5.3 & 3.0 \\
\hline 9 & 9.1 & 5.0 & 4. 9 & 11.4 & 1. 4 & 2.0 & 1.0 & 2.3 & 1. 2 & 1.6 & 1.8 & 2.8 \\
\hline 10 & 2.9 & 7.6 & 6.4 & 4.6 & 3.6 & 3. 6 & 2.5 & 2.5 & 2.5 & 5.6 & 4.6 & 2.8 \\
\hline 11 & 6.7 & 3.3 & 5.8 & 4. 2 & 2. 4 & 2.1 & 1.3 & 2.5 & 5.2 & 3.5 & 2.8 & 3.7 \\
\hline 12 & 1.8 & 2.5 & 4. 0 & 2.0 & 1. 0 & 1. 6 & 1. 7 & 3.6 & 6.5 & 3.1 & 4. 7 & 3.0 \\
\hline 13 & 4. 6 & 5.2 & 5.2 & 3.8 & 0 & 0 & 0 & 1. 3 & 2.7 & 2.6 & 6.4 & 7.3 \\
\hline 14 & 8.1 & 7.0 & 11.8 & 8. 0 & 1.9 & 1. 4 & 1.5 & 1.7 & 3.9 & 6.0 & 5.4 & 3.3 \\
\hline 15 & 15.8 & 9.1 & 9.4 & 2.8 & 1. 0 & 1.9 & 1. 0 & 2.8 & 15.2 & 10.0 & 2.0 & 3.1 \\
\hline 16 & 3.7 & 7.3 & 7.4 & 5.2 & 0.9 & 1. 0 & 1. 0 & 1.1 & 1. 6 & 3.8 & 2.2 & 1.0 \\
\hline 17 & 2.5 & 2.0 & 3.1 & 3.3 & 1. 4 & 1. 7 & 2.7 & 4.7 & 2.0 & 2.7 & 2.3 & 4.0 \\
\hline 18 & 7.5 & 4. 3 & 2.7 & 5.1 & 0.3 & 1. 2 & 0 & 1.8 & 4.7 & 17.2 & 4. 2 & 7.7 \\
\hline 19 & 14.6 & 4.7 & 19. 2 & 9.4 & 5.5 & 7. 4 & 7.3 & 6.2 & 15.8 & 17.6 & 30.9 & 15. 2 \\
\hline 20 & 6.7 & 5.0 & 3.6 & 2.4 & 1.6 & 1.5 & 1. 2 & 1.3 & 4. 4 & 9.8 & 8.3 & 3.2 \\
\hline 21 & 4.6 & 5.0 & 7.5 & 1. 7 & 0.7 & 1. 0 & 1.5 & 2.0 & 3.5 & 1. 3 & 2.1 & 2.2 \\
\hline 平均値 & 5.8 & 5.6 & 6.4 & 5.4 & 1.8 & 2.3 & 2.0 & 2.4 & 5.7 & 6.2 & 5.5 & 4.7 \\
\hline S.D. & 3.7 & 2.8 & 3. 8 & 2.7 & 1.3 & 1. 6 & 1. 7 & 1.5 & 4. 1 & 4.6 & 6.2 & 3. 2 \\
\hline
\end{tabular}

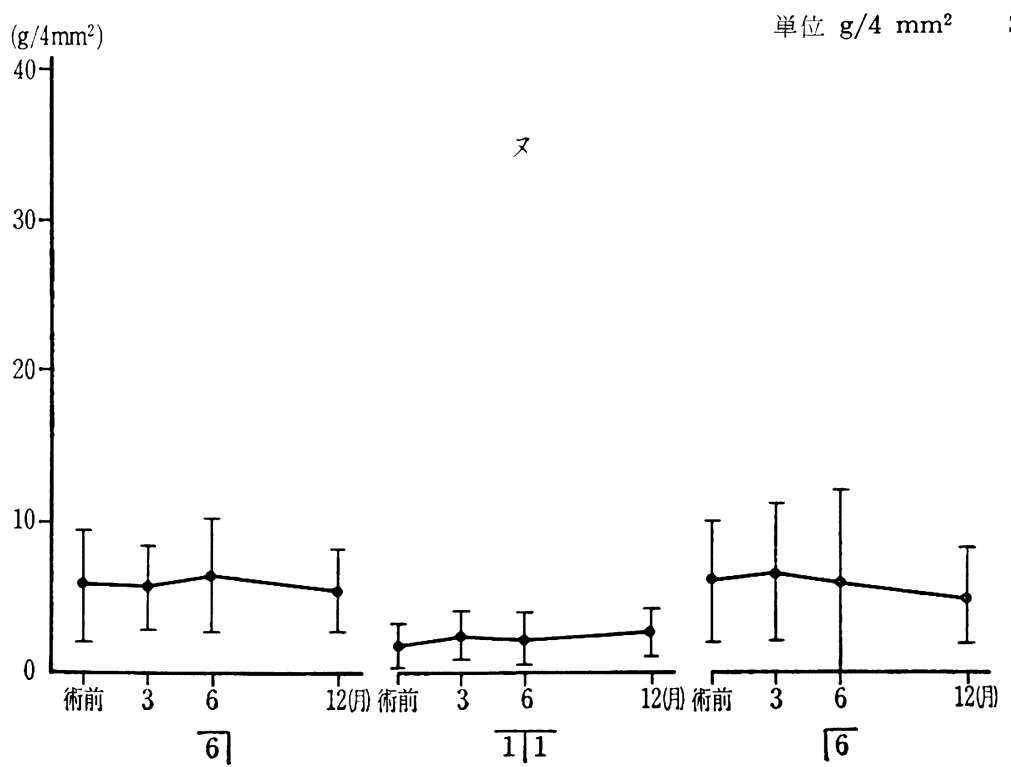

図11〔邓〕発語時に拈ける舌圧の変化 
表 10 [ネ]発語時における舌王の変化

\begin{tabular}{|c|c|c|c|c|c|c|c|c|c|c|c|c|}
\hline 部位 & \multicolumn{4}{|c|}{$\overline{6} \mid$} & \multicolumn{4}{|c|}{$\overline{1 \mid 1}$} & \multicolumn{4}{|c|}{$\sqrt{6}$} \\
\hline 症例 No. & 術前 & $\begin{array}{l}\text { 戔 後 } \\
3 \text { か月 }\end{array}$ & $\begin{array}{l}\text { 術 後 } \\
6 \text { か月 }\end{array}$ & $\begin{array}{l}\text { 術 後 } \\
12 \text { 员 }\end{array}$ & 術前 & $\begin{array}{l}\text { 術 後 } \\
3 \text { か }\end{array}$ & $\begin{array}{l}\text { 政 後 } \\
6 \text { 员 }\end{array}$ & $\begin{array}{l}\text { 術 後 } \\
12 \text { 月 }\end{array}$ & 術前 & $\begin{array}{l}\text { 術 後 } \\
3 \text { か }\end{array}$ & $\begin{array}{l}\text { 愁 後 } \\
6 \text { 员 }\end{array}$ & $\begin{array}{l}\text { 很 後 } \\
12 \text { 员 }\end{array}$ \\
\hline 1 & 5.6 & 9.7 & 8.5 & 13.2 & 2.2 & 2.7 & 1.8 & 3.2 & 10.7 & 11.8 & 10.7 & 13.3 \\
\hline 2 & 5.2 & 9.1 & 6.0 & 8.8 & 0.8 & 4.3 & 2.6 & 3.6 & 6.9 & 5.3 & 8.8 & 9.3 \\
\hline 3 & 10.2 & 8.4 & 8.8 & 8.2 & 1.7 & 2.8 & 1.6 & 1.3 & 14.7 & 14.7 & 13.2 & 12.8 \\
\hline 4 & 10.7 & 8.5 & 17.3 & 17.2 & 5.5 & 3.2 & 6.4 & 3.4 & 11.1 & 18.4 & 18.6 & 14.5 \\
\hline 5 & 8.5 & 12.4 & 11.0 & 9.8 & 1.8 & 1.8 & 0.4 & 1.4 & 7. 0 & 9.9 & 10.4 & 13.5 \\
\hline 6 & 17.3 & 34.2 & 21.8 & 37.5 & 1.9 & 6.7 & 2.2 & 2.2 & 13.2 & 33.5 & 37.1 & 24.6 \\
\hline 7 & 29.8 & 2.7 & 26.2 & 29.8 & 2.9 & 2.0 & 1.3 & 0 & 13. 2 & 9.0 & 14.3 & 15.1 \\
\hline 8 & 10.1 & 22.9 & 19.6 & 12.3 & 1.5 & 2.0 & 1.2 & 1.9 & 6.9 & 18.2 & 14.7 & 5.9 \\
\hline 9 & 49.9 & 34.1 & 28.5 & 41.0 & 3. 6 & 2.3 & 3.1 & 3.5 & 19.8 & 21.9 & 17.7 & 20.2 \\
\hline 10 & 10.5 & 17.7 & 11.9 & 17.7 & 3.3 & 5.5 & 3.5 & 3. 0 & 5.2 & 11.2 & 6.4 & 6.1 \\
\hline 11 & 10.2 & 3. 8 & 6.9 & 7.6 & 3. 0 & 3. 2 & 2.0 & 2.7 & 6.3 & 6.6 & 7.0 & 4.9 \\
\hline 12 & 2.2 & 1.9 & 2.9 & 2.3 & 1.0 & 1.6 & 1.4 & 4.8 & 5.7 & 2.8 & 6.5 & 6.4 \\
\hline 13 & 16.0 & 11.6 & 11.3 & 6.0 & 0.5 & 0.4 & 0.9 & 0.4 & 11.0 & 8.0 & 15.1 & 10.2 \\
\hline 14 & 36.0 & 13.1 & 20.5 & 18.6 & 0.7 & 1.8 & 2.3 & 1.0 & 38.2 & 16.4 & 20.3 & 13.3 \\
\hline 15 & 24.7 & 28.9 & 29.7 & 22.9 & 2.9 & 1.7 & 3. 0 & 1.7 & 28.6 & 37.9 & 3.6 & 22.1 \\
\hline 16 & 6.4 & 8.4 & 5.4 & 11.2 & 0.8 & 1.6 & 1.0 & 2.9 & 10.0 & 5.8 & 4.6 & 5.7 \\
\hline 17 & 5.2 & 7.2 & 10.0 & 7.7 & 1.5 & 2.4 & 3. 3 & 5.0 & 5.1 & 4.9 & 8.7 & 8.3 \\
\hline 18 & 23.0 & 7.1 & 11.1 & 5.3 & 0.5 & 1.6 & 0.7 & 1.8 & 27.2 & 28.8 & 10.1 & 12.7 \\
\hline 19 & 25.4 & 16.0 & 37.5 & 25.7 & 7.4 & 7.4 & 10.4 & 5.8 & 21.6 & 25.6 & 55.5 & 26.8 \\
\hline 20 & 51.8 & 49.0 & 23.4 & 27.0 & 3.3 & 2.6 & 1.7 & 1.6 & 25.0 & 47.1 & 25.9 & 19.6 \\
\hline 21 & 17.6 & 14.8 & 15.5 & 9.1 & 0.8 & 2.6 & 2.5 & 2.4 & 15.7 & 12.5 & 17.9 & 6.4 \\
\hline 平均値 & 18.0 & 15.3 & 15.9 & 16.1 & 2.3 & 2.9 & 2.5 & 2.6 & 14.4 & 16.7 & 15.6 & 12.9 \\
\hline S.D. & 14.2 & 12.1 & 9.3 & 10.8 & 1.7 & 1.8 & 2.2 & 1.5 & 9.1 & 12.0 & 12.0 & 6.6 \\
\hline
\end{tabular}
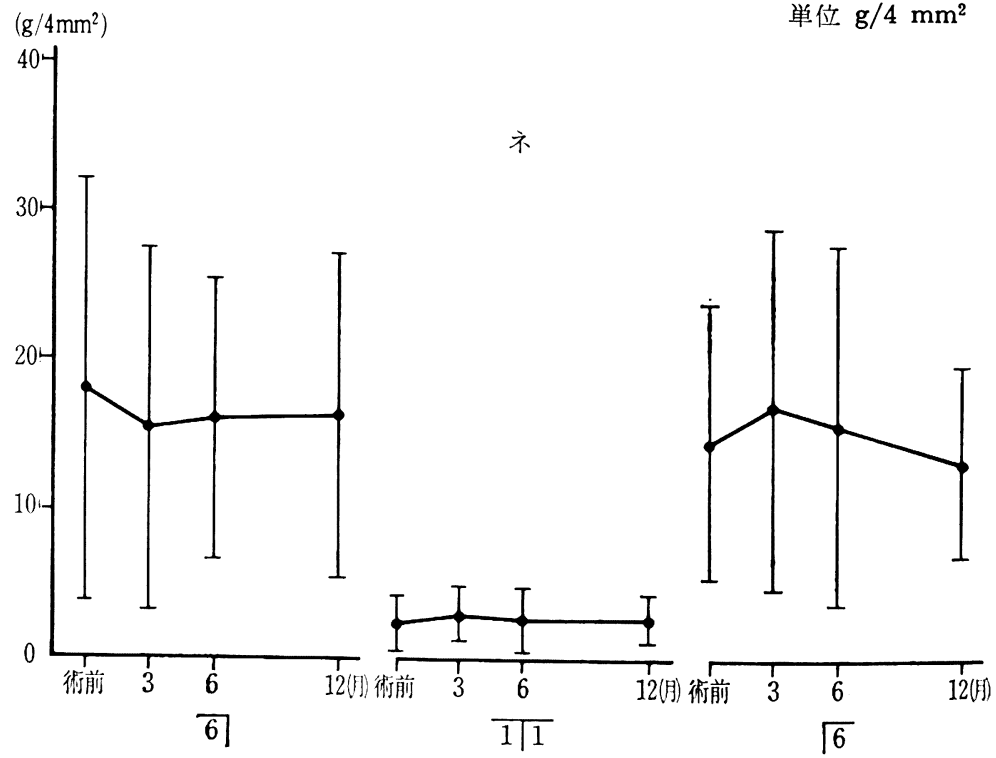

図12〔ネ]発語時に扣ける舌圧の変化 
表 11 〔ノ〕発語時における舌厈の変化

\begin{tabular}{|c|c|c|c|c|c|c|c|c|c|c|c|c|}
\hline 部位 & \multicolumn{4}{|c|}{$\overline{6}$} & \multicolumn{4}{|c|}{$\overline{\overline{1 \mid 1}}$} & \multicolumn{4}{|c|}{$\sqrt{6}$} \\
\hline 症例 No. 経過 & 術前 & $\begin{array}{l}\text { 踟 後 } \\
3 \text { 员 }\end{array}$ & $\begin{array}{l}\text { 術 後 } \\
6 \text { 员月 }\end{array}$ & $\begin{array}{l}\text { 愁 後 } \\
12 \text { 号 }\end{array}$ & 術前 & $\begin{array}{l}\text { 㱐 後 } \\
3 \text { か }\end{array}$ & $\begin{array}{l}\text { 政 後 } \\
6 \text { 只 }\end{array}$ & $\begin{array}{l}\text { 焉 後 } \\
12 \text { 员 }\end{array}$ & 術前 & $\begin{array}{l}\text { 政 後 } \\
3 \text { 只 }\end{array}$ & $\begin{array}{l}\text { 践 後 } \\
6 \text { 员 }\end{array}$ & $\begin{array}{l}\text { 跑 後 } \\
12 \text { 月 }\end{array}$ \\
\hline 1 & 4.6 & 5.8 & 6.3 & 11.5 & 2.4 & 2.0 & 1.9 & 4.4 & 7.8 & 7.9 & 9.2 & 14.7 \\
\hline 2 & 12.1 & 9.3 & 7.0 & 11.2 & 1.3 & 4.8 & 3.3 & 4.1 & 14.1 & 5.4 & 7.8 & 9.2 \\
\hline 3 & 3.8 & 5.4 & 6.8 & 7.2 & 4.2 & 3.1 & 2.4 & 1.5 & 7.8 & 7.3 & 8.2 & 10.0 \\
\hline 4 & 4.1 & 9.3 & 7.3 & 8.0 & 5.0 & 3.6 & 6.8 & 4.2 & 9.1 & 11.6 & 6.5 & 14.8 \\
\hline 5 & 5.7 & 9.2 & 7. 0 & 8.3 & 2.1 & 1.6 & 0.8 & 1.7 & 5.8 & 5.8 & 6.1 & 9.2 \\
\hline 6 & 4.5 & 7.4 & 5.0 & 4.3 & 2.2 & 4.5 & 2.8 & 1.6 & 7.5 & 7.8 & 7.2 & 3.2 \\
\hline 7 & 7.6 & 1.3 & 4.9 & 6.3 & 2.8 & 2.6 & 1.9 & 0 & 4.0 & 5.8 & 4.2 & 3.3 \\
\hline 8 & 5.2 & 9.4 & 10.9 & 9.6 & 1.2 & 2.2 & 1.4 & 1.5 & 6.8 & 12.5 & 14.8 & 4.3 \\
\hline 9 & 10.2 & 6.8 & 6.1 & 12.5 & 3.7 & 1.5 & 2.7 & 3.3 & 5.7 & 6.3 & 3.8 & 5.8 \\
\hline 10 & 7.8 & 15.3 & 8.8 & 9.0 & 2.8 & 10.2 & 3.3 & 3.2 & 2.3 & 16.4 & 8.3 & 3.2 \\
\hline 11 & 12.5 & 3.3 & 8.6 & 12.2 & 7.0 & 9.7 & 3.6 & 5.6 & 5.7 & 8.8 & 7.5 & 8.2 \\
\hline 12 & 2.4 & 3.2 & 4.1 & 2.4 & 0.6 & 1.5 & 1.9 & 4.9 & 9.8 & 3.9 & 8.7 & 6.4 \\
\hline 13 & 6.4 & 13.8 & 13.1 & 8.0 & 0 & 1.7 & 0.6 & 0.2 & 5.8 & 10.2 & 12.7 & 9.5 \\
\hline 14 & 13.1 & 11.2 & 18.1 & 8.3 & 0.7 & 1.9 & 4.4 & 1.8 & 6.4 & 8.7 & 9.6 & 2.7 \\
\hline 15 & 8.5 & 6.2 & 18.1 & 5.4 & 2.5 & 1.9 & 1.2 & 1.8 & 16.0 & 10.1 & 3. 7 & 6.2 \\
\hline 16 & 7.2 & 11.4 & 12.4 & 5.9 & 1.2 & 1.4 & 1.0 & 2.6 & 6.1 & 6.4 & 6.2 & 2.3 \\
\hline 17 & 3.4 & 5.5 & 6.6 & 6.3 & 1.5 & 2.1 & 2.6 & 7.5 & 3.9 & 2.5 & 2.4 & 4.6 \\
\hline 18 & 5.9 & 3.4 & 3.0 & 5.3 & 0.6 & 1.0 & 1.2 & 0.8 & 5.2 & 10.3 & 3.0 & 5.6 \\
\hline 19 & 25.8 & 11.9 & 27.8 & 13.8 & 8.2 & 5.4 & 6.3 & 4.6 & 17.3 & 17.9 & 27.1 & 16.8 \\
\hline 20 & 11.8 & 6.4 & 4.3 & 5.3 & 4.0 & 2.0 & 1.7 & 1.4 & 5.6 & 9.3 & 8.0 & 3.6 \\
\hline 21 & 17.5 & 9.2 & 12.6 & 5.1 & 1.4 & 1.7 & 2.7 & 2.2 & 4.6 & 3.0 & 8.8 & 3.2 \\
\hline 平均値 & 8.6 & 7.8 & 9.5 & 7.9 & 2.6 & 3.2 & 2.6 & 2.8 & 7.5 & 8.5 & 8.3 & 7.0 \\
\hline S.D. & 5.5 & 3.7 & 6.0 & 3.0 & 2.1 & 2.6 & 1.6 & 1.9 & 3.9 & 3.9 & 5.3 & 4.3 \\
\hline
\end{tabular}

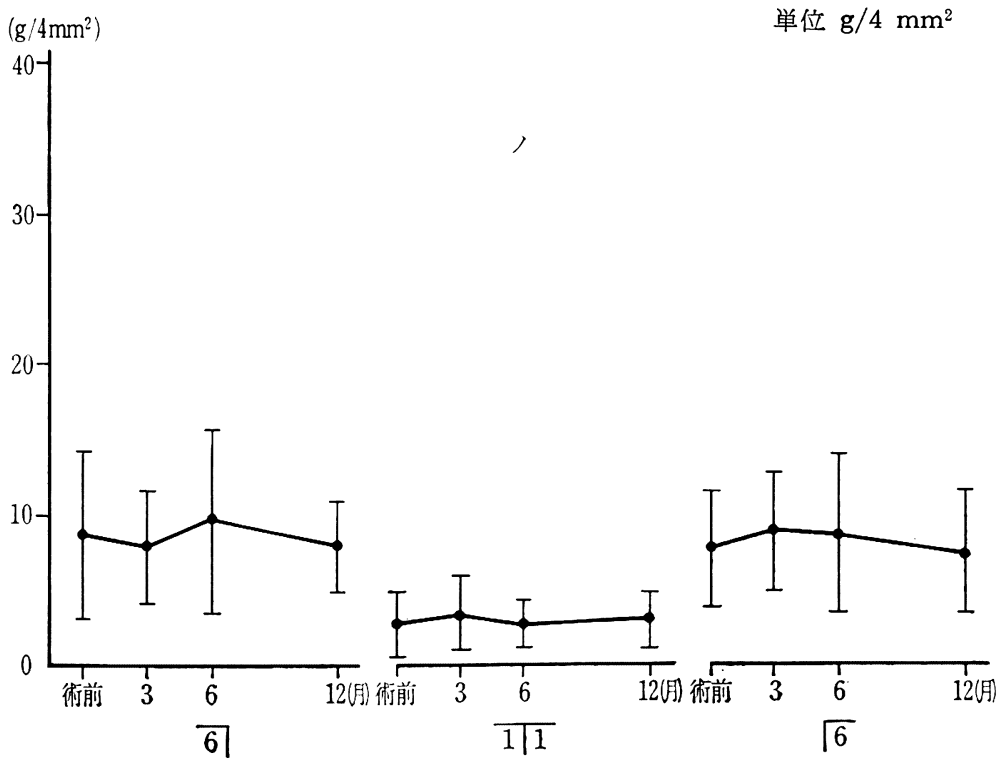

図 13 〔ノ]発語時に括ける舌圧の変化 
表 12 舌圧の変化量の平均値（術前値を基淮とした）

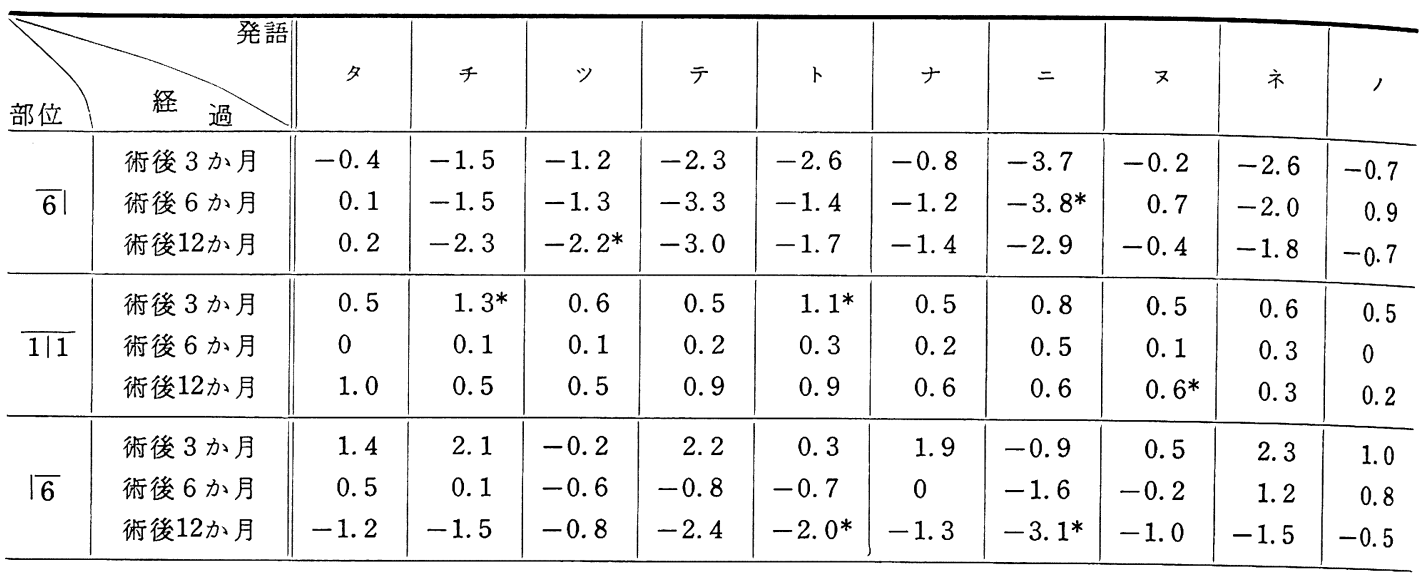

単位 $\mathrm{g} / 4 \mathrm{~mm}^{2} \quad{ }^{*} \mathrm{p}<0.025$

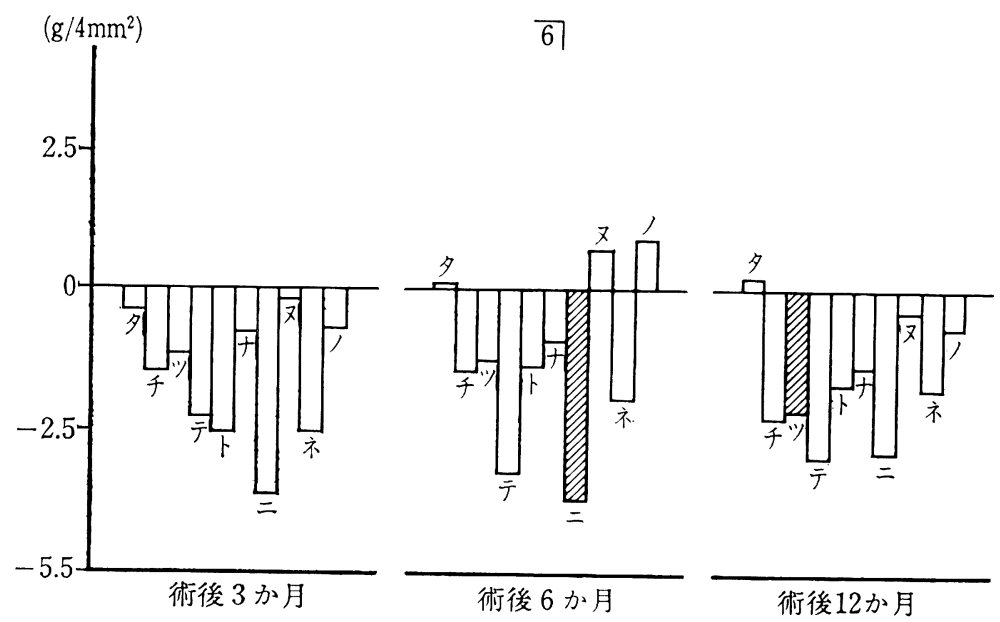

図 $14 \overline{6}$ 部に打故舌圧の変化量

されるよらにしてある。この発語に対応する舌圧波の起 始部からピークまでの垂直距離を計測し，その值を受圧 装置の較正値から圧力に换算した。なお舌圧波の距離 計測は画像処理 システムのデジタイザー（デジグラマ Model $\mathrm{G}$ シリーズ）を利用し，垂直距離に括ける 2 点 をプロットすることにより接続されたミニコンピュータ （キャノン BX-1）から自動的に圧力值に変换された数 值を得られるようにした。

\section{研 究 成 績}

測定の際には被験者に歯音および䨤茎音の40語音をそ れぞれ 5 回ずつ発語させ記録したが，分析においてはそ のなかから明確な舌圧波形を示した〔夕]行音と〔ナ] 行音の10語を抜き出して比較の対象とした。各発語によ り得られた各 5 つの舌圧值のらち最大值と最小値を切り
搭て, 残りの 3 つの值の平均値を算出し各被験者の各発 語時における舌圧の代表值とした，表 2 11は各症例の 各部位における各時期の舌压の代表值ならびにその平均 值, 標準偏差を発語別に分けて表したものである. 各数 值はグラム数に換算してあるが，これは受圧装置の受圧 面の面積 $4 \mathrm{~mm}^{2}$ に加わった舌圧值として単位は $\mathrm{g} / 4$

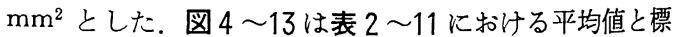
準偏差をグラフに表し，発語別および測定部位別に舌圧 の経時的な变化を示したものである，縦軸は舌王值 $(\mathrm{g} /$ $4 \mathrm{~mm}^{2}$ ) を, 横軸は測定時期 (術前, 術後 3 か月, 6 か 月，12か月）を示している。表12は各症例ごとに術前の 值を基準として術後 3 か月， 6 か月，12か月との差（変 化量)を個々に求めその差 (変化量) の平均値を発語別 および部位別に表したもので，右上に*印のついている 数值は平均值の差の検定において危険率 $5 \%$ で有意差を 示したものである（両側検定を行ったため $\mathrm{P}<0.025$ は 

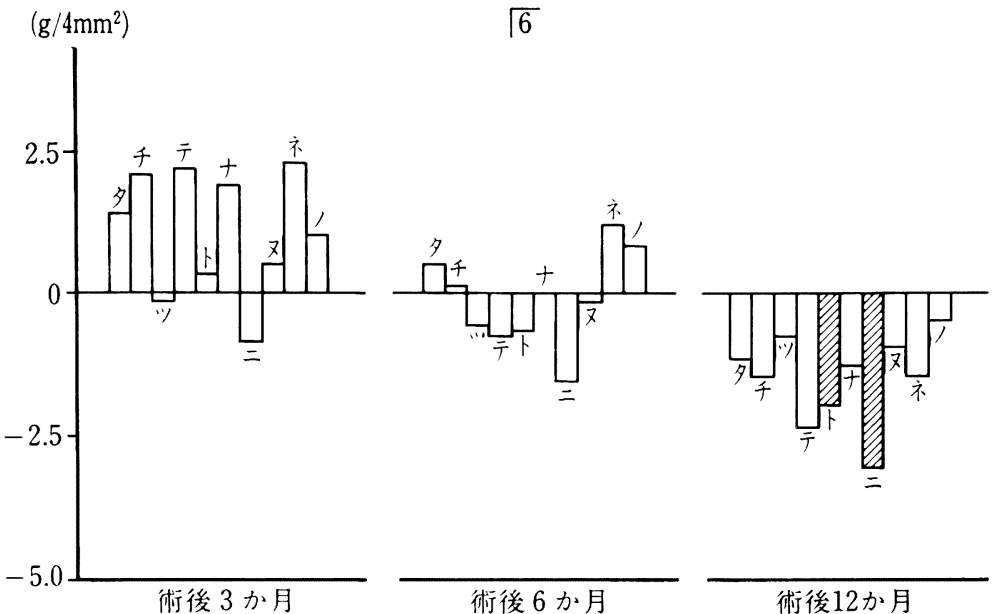

図 $15 \sqrt{6}$ 部に打ける舌圧の変化量
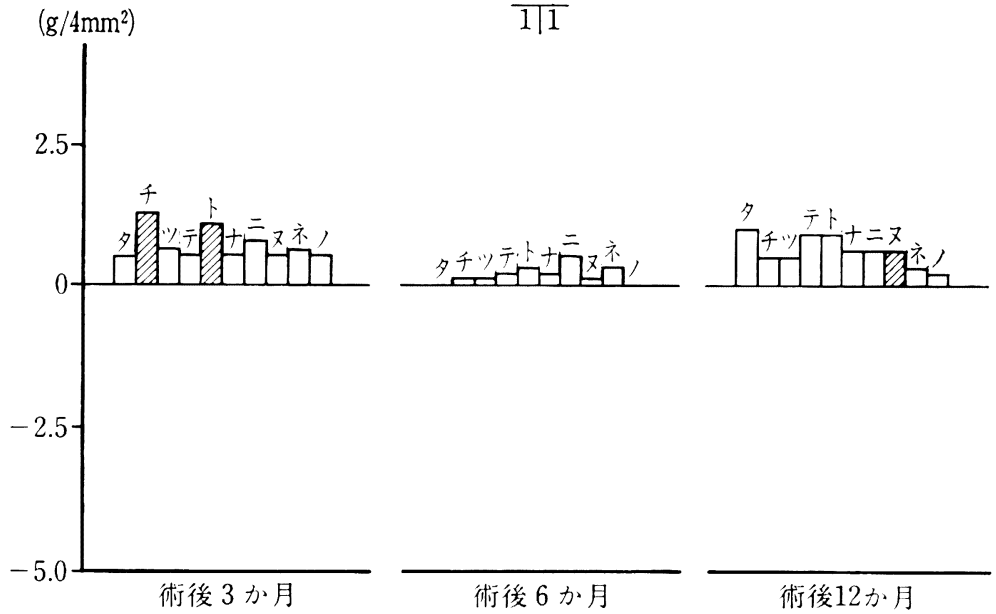

図 $16 \overline{1 \mid 1}$ 部における舌圧の変化量

$5 \%$ 危険率を表している). 図14，15，16は表12に示され た各発語時における舌圧の術後の 変化量の平均值を測 定, 部位別にグラフに表したもので綎軸は変化量（術前 值を $0 \mathrm{~g}$ とし, 単位は $\mathrm{g} / 4 \mathrm{~mm}^{2}$ ) を, 横軸は測定時期（術 後 3 か月， 6 か月，12か月）を，また斜線の棒グラフは $5 \%$ 危険率で有意差のあった変化量を示している.

\section{1. $\overline{6}$ 部における舌圧の変化}

術前の舌圧代表值は各症例により值がまちまちであ り, 最小値は症例 6 の[ツ]発語時における $1.0 \mathrm{~g}$ で最大 值は症例 20 の[テ]発語時に打ける $50.8 \mathrm{~g}$ とその差は 50 $\mathrm{g}$ を示し同疾患, 同条件で測定したにもかかわらず個人 差と発語の種類によって差が大きいことを示している. 平均值でみると. $5 \mathrm{~g} \sim 10 \mathrm{~g}, 10 \mathrm{~g} \sim 15 \mathrm{~g}, 15 \mathrm{~g} \sim 20 \mathrm{~g}$ の 3
つの範囲に大きく分けることができるが，これは発語の 種類によって $\overline{6}$ 部に加わる舌圧の值にも変動が存ずる ことを示している，5g〜10 $\mathrm{g}$ には[ツ][邓][ノ]，10 $\mathrm{g} \sim 15 \mathrm{~g}$ には〔タ〕〔チ〕〔ト〕〔ナ〕，15 g 20 g には 〔テ〕[二]〔ネ]の各発語時の舌圧值が含まれている. 術後 3 か月では, 各発語時ともにすべて術前の值より減 少しており, 減少の程度は〔二]発語時が最も大きくそ の差は $3.7 \mathrm{~g}$ であった。術後 3 か月から6か月の変化で は[千]発語時以外は增加したもの（[タ][ト][又] [ネ][ノ]）と, 減少したもの（[ツ][テ][ナ][二]) に分かれた。術後 6 か月から12か月においても增加した bの（[夕][テ][二][ネ]）と, 減少したもの（[千]

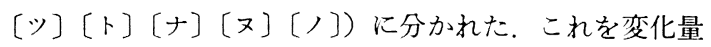


でみると, 術後 3 か月ではすべて術前よりも低值を示す が，術後6か月では〔夕][邓][八]発語時の上らに術 前よりも高值を示すものが表われ，やや上昇傾向にあ る。しかし術後12か月では〔タ]発語時以外は再び術前 よりも低值に下降していた（図14）.

\section{2. $\sqrt{6}$ 部における舌圧の変化について}

術前值はほぼ原部と同程度の值を示しており， $5 \mathrm{~g} \sim$ $10 \mathrm{~g}, \quad 10 \mathrm{~g} \sim 15 \mathrm{~g}, \quad 15 \mathrm{~g} \sim 20 \mathrm{~g}$ の範囲に含まれる発語の 種類もほぼ一致していた。また 1 年を通じての平均舌压 值は $\overline{6}$ 部之同様に〔テ〕および〔ネ] 発語時が 高値を 示していた。術後 3 か月では $\overline{6}$ 部とは逆に〔ッ〕およ び〔二]発語時以外はすべて術前よりも增加しており， 最も増加量が多かったのは[ネ] 発語時の $2.3 \mathrm{~g}$ であっ た. 術後 3 か月から 6 か月の変化ではすべての発語時舌 圧が減少していた，術後 6 か月から12か月ではさらに減 少を続け，すべてが術前よりも低い值になった。これを 変化量でみると, 術後 3 か月では $\overline{6}$ 部とは逆に〔ツ] 〔二] 発語時以外はすべて術前よりも高い值を示したが， 術後 6 か月では術前よりも高值を示す発語と低値を示す 発語上に分か机，下降傾向にある。術後12か月ではすべ ての発語時舌圧が術前よりも低い值を示した（図 15）.

\section{3. $帀$ 部における舌圧の変化}

左右大臼歯部に比べて前歯部に加わる舌圧は低く, 術 前值には $0 \mathrm{~g}$ があり, 症例 12 の[二], 症例 13 の [ ] および〔ノ], 症例 21 の[チ]および〔二]発語時など 多くの症例において見られた。また最高值は症例 19 の 〔チ] 発語時の $13.0 \mathrm{~g}$ であった．平均値でみると術後 3 か月ではすべてが增加しているが，その変化量はわずか で〔チ]発語時が $1.3 \mathrm{~g}$ ，〔ト] 発語時が $1.1 \mathrm{~g}$ を示した が残りのすべては $1.0 \mathrm{~g}$ 以下であった。術後 6 か月では すべてが術後 3 か月より減少し, かなり術前に近い值を 示した，しかし術後12か月では術後 6 か月の時点でいっ たん減少した舌圧が增加をはじめ, ほとんどが $1.0 \mathrm{~g}$ 以 内のわずかな量ではあるが術前よりも高い值を示した。 これを変化量でみると，すべての発語時舌圧が術後 3 か 月， 6 か月，12か月を通じて術前よりも高値で経過して おり術後 6 か月で下降傾向にあるが，それでも術前より も低值を示寸発語時舌圧は 1 つなかった。 $\overline{1 \mid 1}$ 部にお いては各発語時舌圧の変化がすべて同じであり，大臼雪 部に比べるとはっきりとした傾向を示した（図16）。

\section{考}

\section{察}

\section{1. 実験方法について}

1) 対象の選定について

下顎前突症に対する治療法は雨牙のみの移動による咬 合の回復に主眼を拈いた荬列矯正と顎骨の成長発育が完 了した時点で骨格型下顎前突症と診断された症例に対す る外科的矯正法に大別されるが, 本研究の目的は手術に
より人工的にしかも急激に下顎崡列弓を後退, 移動させ た際の歯列弓に加わる舌圧の変化を経時的に観察するこ とであり，対象症例を選定するにあたり，すでに顎骨の 発育が完了した17〜27歳間の青年男女を選び, 発育, 老 化などの影響が出ないように心掛けた。 また手術法にお いては現在最も広く用いられている下買枝矢状分割法 (Obwegeser-Dal Pont 法) を適応した症例のみを対象 とし，同法における舌圧の変化のみを検討することと し, 手術法の違いによる複雑な要素が介入することを避 けた。

\section{2) 受圧装置について}

舌は笳肉臓器でその動きは自在かつ複雑であるため, その圧力を正確に定量化するにはまず優れた受圧装置を 開発することが肝要となる。本研究に用いられた受圧装 置5) は独自に開発製作したもので，リン青銅板と箔ひず みゲージを用い, 形態はカンチレバー 型とし, 長径 8 $\mathrm{mm}$, 幅径 $4 \mathrm{~mm}$, 厚径 $1.6 \mathrm{~mm}$, と小型でプロテクター と外側板がカンチレバー（受圧板）をはさみ込んた 3 層 構造となっており，受圧面以外には舌圧が直接加わらな いように工夫している（図1）。精度については受压装 置の較正において $5 \mathrm{~g}$ 間隔で荷重を負荷し，それにより 得られた出力電圧を対比させたところ直線的な比例関保 が得られている。 また口腔内のように呼気，吸気により 温度が一定に保たれない環境下では温度補償の問題を切 り雄して考学ることはできないが，この点に関しては2 アクティブゲージ法による温度補償回路を採用し，基礎 実験においては温度変化に対する变化率はグラム数に換 算して $1^{\circ} \mathrm{C}$ につきわずか $0.05 \mathrm{~g}$ であった.

3 ）測定に発語時を選んだ意義

舌は咀喘, 嚥下, 発音, 呼吸などの生理的機能に重要 な役割を果たしており，その機能時あるいは安静時にお いても口蓋，䨑列弓内側に圧力を及ぼしている．吉田 は上顩中切歯部の唇舌圧を腄眠時および覚醒時各 8 時間 ずつの長時間测定を行い，歯列に加わる辰压，舌压の時 間圧力䅡を報告しているが，そのなかで覚醒時における 舌の動作時間の割合は 4.0 13.1\% にすぎず，歯列弓に 作用を及ぼす主たる力は静止時の筋圧であると結論し, 経時的な舌圧の变化を観察する際には静止時舌圧を対象 としてその変化を比較するのが妥当としている。しかし 冨田ら ${ }^{4)}$ も述べているように舌の安静位という位置規定 の難かしさや測定器機の精度の限界などから日常臨床に おいて実際の患者から短時間でデータを得るには難があ ると考えられること, 舌本来の機能が発揮されて舌压が 上昇した状態の方がより顎骨に対する影響が大きいと考 え, 本研究に打いては舌の機能の1つである発音に着目 し，発語時舌圧を手術後の経時的な舌圧の変化を知る手

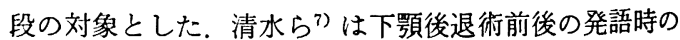
舌の動きを頭部X線規格写真により比べ，術後では全般 に舌は後上方に位置していたと報告している。 また道8) 
はダイナミックパラトグラフィーを応用して下靧枝矢 状分割法を行った症例の歯音, 歯茎音である[タ［サ] 〔引]発語時の口蓋に対する接触状態を観察し, 術後には 接触部位が全体に後方に移動する傾向が見られ，これは 術後に舌位が後方に移動したために生じた变化であるう と考察している．以上の報告をまとめると下靧後退術を 施行した症例の術後の舌の位置の変化は下靧の後退に伴 い後方あるいは後上方に移動し，その位置の变化が発音 時の舌の動作にも反映されることを示している。この事 実は手術の前後における舌圧の変化が発音時に顕在化す る可能性を示唆するものであり, 本研究における発語時 乱圧測定の意義をここに存するものである.

\section{4) 被験音の選定について}

発音の器官としては呼吸筋, 喉頭, 構音器官に分けら れるが, 舌は歯牙, 顎, 口蓋などとともに構音器官とし ての役割を果たしている，構音の際の舌の動きは非常に 複雑であるが，その運動を観察する方法は以前から報告 されている. 荒井9) は60人の被験者に日本語 100 語音を 発音させ，パラトグラフィーを用いて構音時に拗ける舌 運動を描記し，発語時に舌が口蓋に接触する面が前橉部 の歯頸部付近全域にわたっている語音は〔タ]行，〔ナ] 行, [ダ〕行であったと報告しており，また同じく荒井10) は反対咬合を有する症例においても正常人と同様に[夕] 行, 〔ナ〕行, [ダ〕行音が纬頸部全域で舌の接触を示し ているとも述べている。これらの事実は正常咬合者, 反 対珓合者にかかわらず, [タ]行, [ナ]行, 〔ダ]行発 語時には舌は上䫇歯列弓全体の内側に接触し，その接触 の際には上領雪列弓に対して舌圧が加えられることを意 味している。 またその作用は下顎雨列にもほぼ同样に与 兄られるものと考元，本研究においては下顎前突症手術 後の発語時舌圧の経時的変化を調査するにあたり[夕]

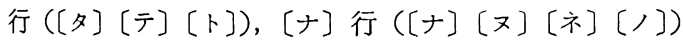
と[チ][ツ]〔二]の計10語を選抜し, 各発語時におけ る舌圧を分析した。これらの10語音は音声学的にみると 〔タ]〔テ〕[ト〕は歯茎破裂音, 〔チ〕は歯茎破擦音,

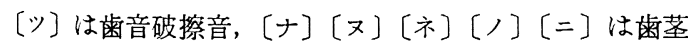
通鼻音と, 構音点はほぼ同じ位置にあるが構音様式は異 なっている11)。また後続母音の種類によって発語時の舌 の動作（構音時の舌の形態）も変化してくるので各症例 において10種類の舌動作に打ける舌圧を経時的に観察し たことになり，下顎に影響を及ぼしうる発語条件をほぼ カバーした状態で実験が行われたものと考えられる。

5) 発語条件について

声の大きさと舌圧との関係については島 ${ }^{12}$ が発音時の 口蓋に加わる舌圧の研究のなかで同一の語音であっても 発音時の声の大きさによって舌压に変動が認められたと 報告しており，声の大きさを一定にすることは測定条件 に欠かすことのできないものである。本研究に㧊いては 前述のごとく発語時音声が設定された範囲内の大きさに
ある時には，記録装置にその表示が現れ確認できるよう にした。

6) 舌圧測定部位の選定について

测定部位によっても舌圧に差が生ずるという報告があ り, 大滝 ${ }^{13}$ は安静時舌圧について前歯部よりも臼歯部の 方が大きかったとして扰り，同様に沖 ${ }^{14}$ は発音時舌圧に おいても大臼霜部は他の部位に比較し高い值を示し，ま た発語の種類によっても舌压の值に変動が生じ，特に大 臼歯部においては後続母音が〔 i とななる語音に大きな 值を示寸傾向がみられたと報告している。したがって本 研究においても前歯部之左右大臼歯部の 3 か所に受圧装 置を設置し同時記録を行い，測定部位の違いによる舌圧 の变化を観察したが，手術前後を通して10語音すべての 発語時舌圧の平均值は前歯部よりも大臼歯部の方が高か った．また発語の種類では後続母音〔 i ]である〔二] が高い值を示したが，それ以上に著明な高い値を示した のは後続母音 [e]の〔テ]と〔ネ]であった.

7 ) 舌圧の測定時期について

本研究に拉いては各症例ごとに術前, 術後 3 か月, 6 か月，12か月と 4 回にわたり舌正測定を行い手術後1年 間の経時的な变化を锶察したが，前述のごとく術前にお ける測定は可能なかぎり手術日に近い時期に行うように した，術後の観察は手術直後に測定を行らのが望ましい が，当然のことながら頜間固定による開口不能により不 可能である。 3 か月としたのはある程度の開口量が得ら れ受圧装置の設置などの操作が支障なく行える時期だか らである。その後の観察については測定回数が多ければ 多いほど詳細なデータが得られるのは確かであるが，対 象は患者であり測定による負担を考虑して 6 か月，12か 月の計 4 回とした。

\section{2. 下顎後退術と舌位と固有口腔について}

下䫇前突症に対する下㴿後退術は1849年にHullihen ${ }^{15}$ が小田歯部の楔状切除を行ったのが最初とされ以後数多 くの優れた手術方法が発表されている. 現在では下顩枝 矢状分割法,下顎骨体短縮術, 前歯部霜槽骨切门術などの 術式が主に採用されているがいずれの術式を選択しても 下顎骨体部あるいは下䫇前方雪列の後方移動によりいち ばん影響を受けるのは舌であると考えられる。本田ら ${ }^{16)}$ は頭部X線規格写真を用いて分析した結果, 術後, 舌 は後方に移動し日時の経過とともに術前の位置に戻る傾 向が認められたと報告し，江俣ら ${ }^{17)}$ 同じ方法で術後の 舌の移動を钼察したが舌根部は後方に偏位し，また舌背 の高さも増加したと報告している．前述のごとく清水 ${ }^{7)}$ ら, 道 ${ }^{8)}$ は発音時の舌の動きを観察し, やはり術後に舌 が後方移動している状態を報告している. 解剖学的に舌 とその隣接諸構造との関係を調べてみると舌は外舌筋で あるオトガイ舌筋により下䫓と, 舌骨舌筋により舌骨と 連結している。また舌骨はオトガイ舌骨筋, 顎二腹笳, 顎舌骨筋に上り下勁頁と連結している。つまり下顎後退術 
後の舌の変位を論ずる際には, 舌, 舌骨, 口底, 下顎を 分離して考えるわけにはいかない，下頣枝矢状分割法は 下顎枝部を矢状方向に分割し，下顗歯列弓を含む下䫇骨 体部を後方に移動させるため, 下顎と舌と口底が一体と なって後方に移動する。したがって舌と下顎前歯部歯列 との相対的な位置関係はそれ程大きく変化しないため， 前歯部における舌圧の变化の程度も比較的少ない範囲に

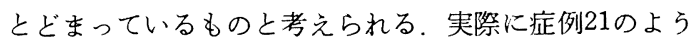
に下顎後方移動量が最も大きかったものでも術後 3 か月 における前歯部舌圧の变化は $0.1 \mathrm{~g}$ から $1.8 \mathrm{~g}$ の範囲に とどまっている.

下顎骨体短縮術，前歯部歯槽骨切り術においても舌の 後方移動は生ずるわけたが，骨切りの部位の相違により 下顎枝矢状分割法のよ5に舌全体の後方移動は起こら ず，したがって前雨部における術後の舌圧の変化もより 大きなものになると推定されるが，この術式の違いによ る舌圧変化の比較については今後の課題と考えている.

下買の後退に伴う口腔の変化としては舌の後方変位も さることながら, 固有口腔の狭小化も念頭に置かなくて はならない 舌は自在にその形を変化させることができ るが体積までも変化させることはできず，狭くなった固 有口腔において舌体積と口腔容積との比率に変化が生じ てくる. 高田 ${ }^{18)}$ は舌体積と固有口腔容積を計量比較し, 舌 と口腔の大きさの間には一定の調和のとれた対応関俰が 成立しており，この両者の関係は Moss $5^{19)}$ の生体が呼 吸に必要な機能空間を維持するための生物学的反応に基 ついているという考え方を支持している，したがって人 工的に下顎を後退させて舌体積と口腔容積のバランスが 崩れた場合, それを元の状態に戻そらとする変化が現れ てくるはずであり, 兽矢ら ${ }^{20)}$ の報告をみると術後矯正中 にP Pog. の位置は16例中14例が前方移動したと述べてい る.しかしながら後退させた下顎が全く元の位置まで後 戻りしたといらような報告は全くなく, 生体の適応性に よる固有口腔の狭小化の固定を考虑に入れる必要があろ 5. 舌の適応性に関しては, 田口 ${ }^{21)}$, 板垣ら ${ }^{22)}$ の報告の よらに優れているとする意見と, 勢島ら ${ }^{23)}$, Glass ら ${ }^{24)}$ のよ5に反対の意見もある。いずれにせよ舌の適応性だ けで狭くなった固有口腔を補償することは不可能であ り, その他に口底, 舌骨, 下顎骨などの移動による補償 機転が働くはずである。術後の経過中における舌圧の微 妙な変化は，下䫄の後退により生じた舌位の変化や固有 口腔の狭小化に対して元の状態に戻そらとする生体反応 と, 変化した状態に慣れようとする生体適応性が複雑に 絡み合いながらつくり上げた舌と下顎米列弓との相対的 関係の変化を反映しているものと考えられる。

\section{3. 成績について}

1 ) 術前値について

術前の舌圧代表値は同じ発語においても症例間におい、 てもその差が激しく, 同じ下顎前突症であっても舌圧に
関するかぎりかなり大きな個人差を示すことが認められ た。これはおそらく健常人に打いても当てはまることで あろらと考えられる。発語別にみてみると, 発語の種類 によって舌圧値に差があり，大日雨部において顕著であ った。これは構音の際の舌の形態の変化が被験音によっ て異なり，それによって歯列に加わる舌圧にも変化が生 ずるためであろう，測定部位（受圧装置の設置部位）に よっても舌王値に変化があり, 前歯部と大臼歯部を比較 した場合, 明らかに大臼歯部における舌圧值の方が大き く, 大滝 ${ }^{13)}$ の安静時舌圧についての報告も併せ考える と, 歯列に加わる舌圧は安静時, 機能時を通じて常に前 歯部よりも臼歯部の方が大さいことが認識された。

2 ) 前歯部 (II1) 舌圧の術後変化について

術前値を基準とした変化量でみると, 被験音として用 いた発語時舌圧の個々の変化のパターンはすべて同じで ある。つまり術後 3 か月で上昇し, 術後 6 か月ではやや 下降し，なかには〔夕][ノ]発語時のように術前値に 戻ったものもみられるが, 術後12か月では再び上昇して おり術後 1 年を通じて術前値よりも下降する発語は1つ もなかった（図16）。下顎枝矢状分割法においては前述 したよらに舌も後方へ同時移動するが，それでも前歯部 に加わる舌王は多少なりとも術前より高い状態で存続し ており，術後の後戻りの要因のひとつになりらることが 示唆された。

3 ) 大臼歯部 ( $\overline{6} \mid$ ) 舌圧の術後変化について

変化量でみると, 術後 6 か月における[タ][邓][八 および術後 12 か月における[夕]発語時以外は術後 1 年 を通じてすべて術前よりも低い値をとりながら経過して おり，前歯部における術後変化とは相反する結果を示し ている（図 14）．下顎の後退に伴う口腔容積の減少によ り歯列に及ぼす舌圧も増加するのが当然と考えられる が，逆に大臼米部において術後に低下しているのは舌の 機能時の力が減弱したとするよりは，下靧の後退ととも に舌位も変化し下顎大臼歯部（受圧装置の設置部位）と 舌之の相対的位置関係, とくに上下的位直関係の変化に よるものと考えるのが妥当と思われる.

4 ) 大臼歯部 ( $\overline{6}$ ) 舌圧の術後変化について

変化量でみると，術後 3 か月では[ツ]〔二]発語時 以外は前歯部と同様にすべて上昇しているが, 術後6か 月では術前よりも高值を示すものと低値を示すものがほ ほ半分ずつに分かれ，術後12か月では可部と同様にす ベての発語時舌王が術前値よりも低下している．1 年間 の経過としては術後早期には上昇寸るがその後は下降の 一途をたどるといら傾向を示している（図 15）。受王装 置の設置に関しては，左右大臼歯部の 対称となる 部位

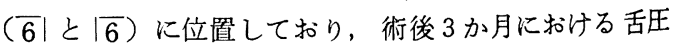
の加わり方が左右で異なった傾向を示したのは表 1 に示 すような左右後退量の差による一時的な現象ではないか と推定される。 
5) 前歯部舌圧と大臼歯部舌圧の術後変化の比較につ いて

本研究の対象とした症例はすべて下䫇枝矢状分割法に 属する Obwegeser-Dal Pont 法が施されており，この術 式の選択により前述のごとく下顎の後退とともに舌全体 の後方移動も起こり, この舌位の变化が舌圧の術後変化 几大きく反映されているものと推察される。ここで舌 と密接な関係をもつ舌骨の位置変化をとらえてみると Wickwire $5^{25)}$ は術後の初期順応の後もとの位置に戻る 傾向にあると述べており，Takagi $5^{26)}$ は下顎枝矢状分 割法を行った症例の術後の頸椎に対する舌骨の位置変化 を調査したが，前後的な位置の変化はわずかしか示さな かったとしている。同样に江俣ら ${ }^{17)}$ 頸椎に対する舌骨 の位置変化は少なく，それも上下的な変化が主であり， また舌骨と下頭を連結するオトガイ舌骨筋, 顎二腹筋前 腹の長さが術後に短縮したと述べている。このような事 実は下顎と舌の後退に伴ら気道狭窄を防ぐための補償機 転が舌骨を前方に維持するといらかたちで現れていると 考えられている，とすると，気道を確保するために舌根 部は十分に後方にさがれず，結果的には江俣ら王) も記し ているように舌はその形態を变化させて後上方に偏位す ると考えるのが妥当と思われる。下顎枝矢状分割法は舌 の後方移動も伴うため, 前雪部雪列と舌前方部との相対 的位置関係は大きく変化しないが，以上のような舌骨の 位置移動が少ないための舌形態変化が, 軽度の前歯部舌 圧上昇といら結果を生むものと推定される.

大曰歯部 $(\overline{6} \mid)$ に拈いては前雨部とは逆に術後 3 か 月の時点から術前値よりも低下している。前述のごとく 乱後上方に移動し, 特に舌の後部においては上方に挙 上された状態となり，大臼歯部（受圧装置の設置部位） との相対的な上下的位置関係が大きく変化したため, 下 頱大臼歯部に加わる舌圧が低下したものと考えられ，こ れが術後 1 年間低下した状態で経過しているのは術後に 辞が後上方に偏位したままであることを示しており，こ の点を考劣た場合, 発語時の構音点の変化などは無視で きない問題点であろう.

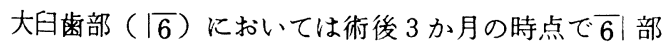
とは逆北前よりも高值を示しており, 左右で傾向が異 なっているのは一見理解し難い感じであるが，これは下 靧を後退させる際の後退量が左右によりわずかながらの 違いがあり（右側では平均 $8.9 \mathrm{~mm}$, 左側では平均 7.8 $\mathrm{mm})$, 下顎骨体の回転が起こり, 舌は後上方に移動した ものの左右に舌運動機能空間の差が生じたためではない かと推定している。しかしながら術後 6 か月，12か月で は $\overline{6}$ 部と同様に舌圧が減少する傾向を示しており, こ の間における舌と顎の適応現象が推定される，以上を総 括的に見ると, 下顎歯列弓に対する舌圧の術後変化は, 前 歯部においては上昇した状態で経過し，大目歯部におい ては低下した状態で経過するとまとめることができる。

\section{4. 舌縮小術の併用について}

下㖽後退術を行うにあたり, 固有口腔容積と舌体積と のバランスをなるべくくずさないよらに，ひいては舌圧 を上昇させない上うにとの立場から舌を縮小してはどう かといら考え方がある。高橋ら 27 は客観的に巨舌と思わ れる下顎前突症例や，開珓を伴万下䫇前突症例に対して 舌縮小術を併用した結果，いずれの症例にもあと戻りの 傾向は全くみられなかったとしており，下向ら ${ }^{28)}$ は唇龥 裂を伴った下顎前突症例に舌縮小術を併用し，やはりあ と戻りの兆候がなかったと報告している.同じくSwanson $^{29)}$ ，Malakouti ${ }^{30)}$ らも舌縮小術の併用を評优してい る。著者の成績では下彭頁枝矢状分割法に限定した条件下 ではあるが，舌圧上昇は意外と小さく，また舌縮小術を 行った自験例では舌王は術後早期には術前よりも减少す るが, その後增加する傾向があり, 舌圧の面からみると 舌の体積を減量することで顎位のあと戻りを防止しょう との考えは無理なよらに思われ, 下顎後退術と舌縮小術 を短絡的に結びつけてしまらのは早計かと思われる。

\section{結}

\section{論}

下顎前突症手術後の発語時舌圧の経時的な変化をとら える目的で，下䫇枝矢状分割法 (Obwegeser-Dal Pont 法）を施行した21症例を対象として下顎前歯部, 左右大 臼歯部の 3 か所滛受圧装置を設置し，10語音（[タ][テ]

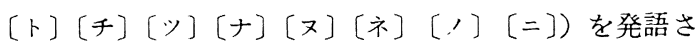
せた際の舌圧を各発語ごとにまとめ, それらを総合して 術後 1 年間にわたる舌圧の経時的な変化について分析を 行った。その結果は以下のごとくであった。

1. 術前における舌圧值は個人差が大きく，下靧前突 症例における舌圧值は同定できなかった。

2. 測定部位によって舌圧值に差があり，大臼霜部は 前歯部に比べて術前術後を通じて高い值を示した。

3. 発語の種類によっても舌圧值に差があり，大臼雨 部においては後続母音が〔 e ] の発語時舌圧が術前術後 を通じて高い值を示す傾向がみられた。

4. 左右大臼歯部にお汁る舌圧の経時的な变化は，術 後 3 か月と 6 か月においては術前よりも增加するものと 减少するもの之に分かれたが，12 か月の時点では $\overline{6}$ 部 に打ける〔夕〕 発語時以外忖すべて術前よりも低値を示 した。

5. 前歯部における舌圧の経時的な変化は術後 3 か月 で術前よりも增加し，6 月月ではやや減少し術前値に近 づくが，12か月では再び增加した，前荬部においては術 後 1 年間を通じてすべての発語時舌圧が術前よりも高值 を示しながら経過した。

稿を終えるにあたりこ校閲を晹わった恩師河合幹教授 に樑甚なる感謝の意を捧げます。またこ指導を睗わった 
堀田文雄講師および生理学教室, 河野通之講師そして研 究に際しご協力を睗わった阿部本晴講師に心より感謝い たします。あわせてこの研究に対して種々ご協力下さっ た兜森正道, 大岩雅則, 加藤久善各氏をはじめ教室員各 位に拉礼申し上げます。

\section{引用 文 献}

1）大喜多幸子：舌房樎小が下嚬姿势に及ぼす影 響. 九州蔯会誌 36：696-720 1982.

2）児玉紳介：実験的舌房縮小に打古舌圧の経日 的変化. 九州菌会誌 38：1128-1142 1984.

3) 日比野好行, 高森 等, 他: 下顎前突症患者の 後退術前後に打ける舌王の経時的変化につい て. 歯学 72: 59-112 1984.

4）冨田滋, 高森 等, 他：下㴿後退犹後の舌王 と後戻りについて。日外誌 32：1173-1191 1984.

5）成田幸憲, 兒森正道, 他：口腔笳王測定の装置 および方法について。 日 口外誌 33：264-269 1987.

6）吉田恭彦：正常咬合を有する成人の上顎中切迷 部唇舌圧の長時間測定による研究。雬科学報 75: 1156-1183 1975.

7）清水達夫, 大矢信夫, 他: 形成外科的手術老施 した下䂓前突症患者に就いての音声学的観察。 京大口科紀要 5：86-96 1965 .

8) 道 健一：口腔疾患による言語障害の診断と治 療に関する臨床的研究。口科誌 35：1035-1076 1986.

9）荒井䝨一：パラトグラムによる日本語調音の生 理学的研究 第一篇 正常篇. 椟科学報 58: 1191958.

10）荒井賢一：パラトグラムによる日本語調音の生 理学的研究 第二䉘 異常篇. 萪科学報 58: 161958.

11）田口恒夫：言語治療用ハンドブック。第 8 版, 日本文化科学社, 東京, 1977,2 -24頁.

12）島保幸：日本語語音発音時の口蓋に対する舌 圧について。科誌 17: 376-387 1968.

13）大滰晃一：舌の大きさと圧力に関する研究。菌 学 $72: 163-1861984$.

14）沖淳：機能印像に関する㳙圧の研究一下頡

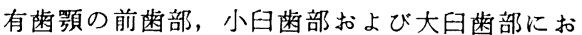
ける水平舌压について一。蔽学 66: 786-814 1979.

15) Hullihen, S.P.: Case of elongation of the under jaw and distortion of the face and neck, caused by a burn, successfully treated. Am J Dent Sc 9: 157-165 1948.

16）本田富遃，伊藤利明，他：下顎前突症扣よび開
咬症に対する外科的矯正手術前後における舌位 置の変化について。（抄)口科誌 25: 6081976.

17）江俣和代，三谷英夫，他：骨格型下顎前突症に 対する外科的䝷正治療の影幚。一とくに軟組織 側貌・咽頭部気道の形態おょび舌骨の位置変化 について一。 日矯雨誌 42: 69-84 1983.

18）高田健治：舌体積と口腔・顔面形態の相互関係 に関する研究—成人正常咬合者拉よび前茵部開 咬者について一。阪大菌誌 26: 328-358 1981.

19) Moss, M.L. and Salentijin, L.: Differece between the functional matrices in anterior open bite and in deep over bite. Am J Orthod 57: 264-279 1971.

20）曾矢猛美, 神田典生, 他：下顎枝矢状分割法を 適用した skeletal class III の術後の安定性の㭘 討。 日矯茀誌 42：288-296 1983.

21）田口恒夫：粕牙の異常・舌の異常と言語障害. 隧界展望 16：110-118 1959.

22）板垣正樹，菅原淮二，他：骨格型反対咬合者の 舌の調音運動, 下顎運動および音声の同時観察 -Long face・ Open bite 群と Short face - Deep bite 群との比較一。 日矯菌誌 45:237-249 1986.

23）勢島 実, 板垣正樹, 他: 成人反対咬合者の外 科的稪正治療による口腔形態の変化と舌の調音 との関係一電気的パラトグラフィーによる钼 察一 日矯菌誌 42: 273-287 1983.

24) Glass, L., Knapp, J., et al.: Speech and lingual behavior before and after mandibular osteotomy. J Oral Surg 35: 104-109 1977.

25) Wickwire, N.A., White, R.P., et al.: The effect of mandibular osteotomy on tongue position. J Oral Surg 30: 184-190 1972.

26) Takagi, Y., Gamble, J.W., et al.: Postual change of the hyoid bone following osteotomy of the mandible. OS OM \& OP 23: 6886921967.

27）高橋庄二郎, 重松知寛, 他: 顎発育異常の外科 的治療に関連する舌縮小脯について。 口科誌 27: 334-342 1978.

28）下向保子, 野口規久男, 他：外科手術を要した 骨格性下顎前突の 2 矯正治験例一とくに舌の咬 合の安定性におよぼす影掣について一。日稪菌 誌 39: 251-264 1980.

29) Swanson, L.T. and Murray, J.E.: Partial glossectomy to stabilize occulusion following surgical correction of prognathism. OS OM \& OP 27: 707-715 1969.

30) Malakouti, B.: Combined procedures in corrective surgery of prognathism and associated deformities. J Oral Surg 28: 506-515 1970. 